\title{
The early diffusion of the steam engine in Britain, 1700-1800: a reappraisal
}

\author{
Alessandro Nuvolari • Bart Verspagen • \\ Nick von Tunzelmann
}

Received: 2 August 2008/Accepted: 14 February 2011/Published online: 5 March 2011

(C) The Author(s) 2011. This article is published with open access at Springerlink.com

\begin{abstract}
We examine the diffusion of steam technology across British counties during the eighteenth century. First, we provide new estimates for the regional variations in the timing, pace and extent of usage of steam engines. Our main data source is an updated version of the list of steam engines erected in Britain during the eighteenth century originally compiled by Kanefsky and Robey (Technol Cult 21:161-186, 1980). Following a rather established approach for analysing the diffusion of new technologies we fit S-shaped growth functions to the data on the numbers of steam engines installed in each county. In this way, we are able to provide a comprehensive appraisal of the relative speed of the diffusion process in different counties. Second, in order to assess the relative importance of the variables shaping the diffusion of steam power technology, we study the relationship between the number of steam engines installed in each county and localization factors such as coal prices, availability of water sites, number of textile mills and number of blast furnaces.
\end{abstract}

Keywords Steam engine - Diffusion · Great Britain · Industrial revolution

JEL Classification $\quad \mathrm{N} 73 \cdot \mathrm{O} 14 \cdot \mathrm{O} 33$

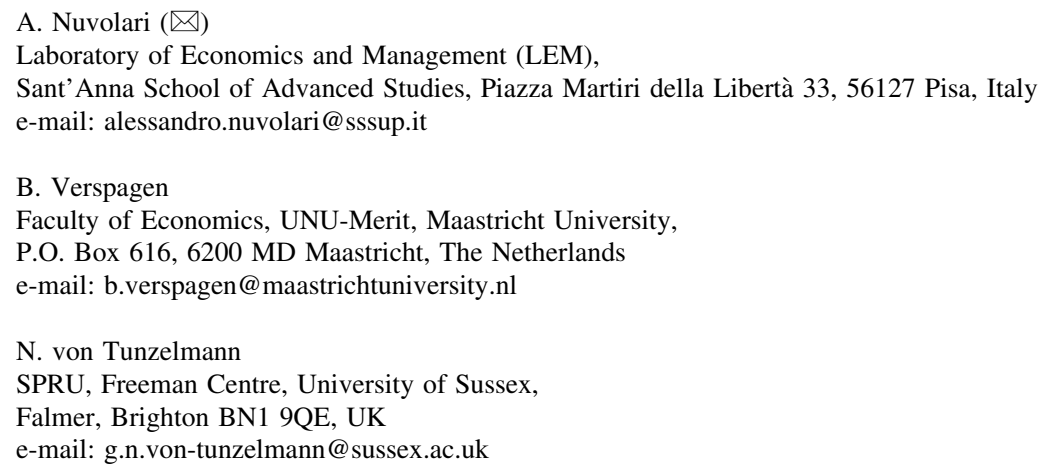




\section{Introduction}

The steam engine has still a central position in the economic history of the British industrial revolution. Today, it is generally recognized that traditional accounts of the industrialization process such as those of Rostow (1960) and Landes (1969) tended to conflate the economic significance of the steam engine with its early diffusion. In fact, the available shreds of evidence on the growth of steam power in the British economy in combination with data on the cost effectiveness of early steam engines indicate that steam power gave a only modest contribution to aggregate productivity growth until at least the 1830s (Von Tunzelmann 1978, Crafts 2004a, b).

However, it is important to stress that these revisionist accounts concern the timing of the economic effects of the diffusion of steam power technology and do not intend to question the fundamental role played by this technology for economic growth over the long-run. Thus, the views of Cipolla (1962) and Wrigley (1988, 2004) which regard steam power as a critical technological breakthrough that changed the energy budget of the British economy providing the opportunity for tapping into inorganic stocks of fossil fuels (coal) and thereby reaching a steeper growth trajectory (usually referred to as "modern economic growth") are not in principle in contrast with the findings of Crafts and von Tunzelmann. Recent developments in growth theory have actually pointed out a series of factors which can explain why the impact of a general purpose technology such as the steam engine on the rate of economic growth is going to be affected by long delays (Lipsey et al. 2005; Bresnahan 2010).

This cursory summary suggests that the broad contours of the relationship between the diffusion of steam power and economic growth have been probably successfully outlined. However, this concerns only the aggregate dimensions of the diffusion process. In fact, several contributions have actually argued that a proper understanding of the processes of economic change occurring during the British industrial revolution needs to be based on a regional perspective (Pollard 1981; Langton 1984; Hudson 1989; Berg and Hudson 1992). These authors claim that industries exhibiting fast rates of output growth and extensive technical and organizational changes displayed a strong tendency towards regional concentration. ${ }^{1}$ From these considerations, it is clear that, when accounting for the diffusion of a technology in this period, due attention must be paid to regional aspects.

Kanefsky (1979) and Kanefsky and Robey (1980) have assembled a comprehensive data-set on the adoption of steam power in Britain throughout the eighteenth century. On the basis of these data, they have provided a quantitative descriptive outline of the diffusion process (Kanefsky and Robey 1980). This paper serves a twofold purpose. The first aim is to expand on Kanefsky and Robey by providing a new quantitative characterization of the timing, the pace and the geographical extent of steam engine diffusion during the eighteenth century adopting a framework of

\footnotetext{
1 This emphasis on the importance of geography is actually also somewhat implicit in the Crafts and Harley (1992) position via the emphasis given specificities of the growth experience of the (Lancashire) cotton industry.
} 
inquiry based on the economics of technological diffusion. The second goal is to assess the factors influencing the adoption of steam engine technology in different locations. In particular, we want to test systematically the role played by the price of coal, which the studies of von Tunzelmann (1978, pp. 47-92) and Kanefsky (1979) have identified as the critical factor affecting steam engine usage. In this respect, it is worth noting that both the studies of von Tunzelmann (1978) and Kanefsky (1979) were based on estimates of the cost effectiveness of "representative" Newcomen and Watt engines at different level coal prices integrated by some anecdotal evidence (e.g. von Tunzelmann 1978, pp. 76-78), but they did not investigate systematically the existence of an actual correlation between coal prices and the number of engines installed at regional level. ${ }^{2}$

The rest of the paper is organised as follows. In the next section we present a brief overview of the development of the steam power technology in the course of the eighteenth century. Clearly the aim of this section is to provide the necessary background (from the history of technology point of veiw) to our diffusion study. In Sect. 3, we provide a broad outline of the geographical diffusion patterns of Newcomen and Watt engines. Section 4 examines the timing and pace of steam engine diffusion at the level of individual counties. In Sect. 5, by estimating "adoption equations" of various types of steam engines by county, we assess the relative role of a number of specific location factors. In the same section, we also attempt to interpret the results of our econometric analysis against the background of the existing historical accounts of the emergence of steam power technology. Section 6 draws conclusions.

\section{The development of the steam engine during the eighteenth century}

In the late seventeenth century mining activities began to be severely hampered by flooding problems. Following the scientific investigations of Torricelli and Pascal, there were several attempts to use atmospheric pressure to lift water out of mines. The Savery engine, clearly inspired by the scientific investigations of the time, can be considered as the first successful effort in this direction. The engine was developed in the period 1695-1702. In the Savery engine, steam was first admitted and then condensed inside a "receiving" vessel by pouring cold water over its outside. Following steam condensation, atmospheric pressure drove the water to be pumped up into the vessel. The engine suffered from two major shortcomings, which severely limited its practical utilization. The first defect was the restricted height of operation: the suction lift could raise water only to a height of 20 feet (about six metres). The second was the high fuel consumption due to the need to recreate steam inside the vessel at each stroke. Undoubtedly, the historical importance of the Savery engine lies more in showing the general potentialities of the use of

\footnotetext{
2 A study similar to the one carried out in this paper has been performed by Atack et al. (1980) for the adoption and regional diffusion of steam power in the United States over the period 1776-1900. In a study related to the present paper, Nuvolari and Verspagen (2009) examine the patterns of diffusion of the high pressure engine in Britain in the period 1800-1850.
} 
steam power rather than in its practical applications, although a number of such engines continued to be in actual use for several years.

The Newcomen engine, developed in the early 1710s, resolved the problem of the limited height of operation. The engine consisted of a piston-cylinder arrangement connected to one arm of a working beam. The opposite end of the working beam was connected to the mine pump-rod. Steam was admitted from the boiler into the cylinder by means of a valve. Then a cold jet of water was sprayed into the cylinder, condensing the steam. This created a partial vacuum inside the cylinder, so that the piston was pushed down by atmospheric pressure ${ }^{3}$ (the top of the cylinder was open), lifting the pump-rod at the other end of the beam. The use of the cylinder-piston arrangement together with the beam made possible the use of the engine for effective mine drainage, as pump-rods could easily be extended to reach the necessary depth. Furthermore, the Newcomen engine was robust, highly reliable and based on a fairly simple working principle. Given these merits, it is not surprising that Newcomen engines soon came into widespread use in mining activities. However, the Newcomen engine had two main technical shortcomings. As with the Savery engine, one deficiency was the high fuel consumption due to the need for cooling and heating the cylinder at each stroke. The second limitation was the irregularity of its movement, which prevented the use of this kind of engine for directly delivering rotary motion. ${ }^{4}$ Savery and Newcomen formed a partnership to exploit the patent rights of their inventions (Savery had been granted a patent for his invention in 1699). The patent expired in 1733.

The problem of the high fuel consumption of the Newcomen engine was successfully tackled by James Watt in the late 1760s. In the Watt engine condensation was carried out in a separate vessel and not in the cylinder, so there was no need to re-heat the cylinder at each stroke. The Watt engine, like the Newcomen engine, consisted of a piston-cylinder arrangement connected with a working beam, but the piston was pushed down by the action of steam and not by atmospheric pressure (the cylinder had a closed top). After having pushed down the piston, the steam was admitted by means of a system of valves into a separate vessel where it was condensed. This allowed for a much higher fuel economy compared to the Newcomen engine.

In the second half of the eighteenth century, there were also a number of attempts to introduce modifications to the Newcomen engine so that it could deliver a steady rotary motion. The most convenient solution was patented in 1780 by James Pickard. It involved the combined use of the crank and a flywheel (Hills 1989, p. 60). At more or less the same period, Watt, at the insistence of his business partner Matthew Boulton, was also working on the transformation of reciprocating into rotary motion. Pre-empted by Pickard in the use of the crank, Watt was forced to contrive an alternative mechanical device, the "sun and planet" gear. However, after the expiration of Pickard's patent, in 1794, Boulton and Watt resorted to the

\footnotetext{
${ }^{3}$ For this reason, Newcomen and Savery engines were also commonly termed "atmospheric" engines.

4 A number of Newcomen engines were successfully used to raise water over a water wheel which, in turn, delivered rotary motion for factory machinery. This type of engine was usually called a "returning engine". One major limitation of this engine was that the inefficiency of the water-wheel was combined with the inefficiency of the engine. See Hills (1989, p. 49).
} 
use of the simpler and more effective crank (von Tunzelmann 1978, p. 20). The conversion of reciprocating into rotary motion was also facilitated by the development of the double-acting engine, another invention by Watt, which was patented in 1782. In the double-acting engine steam is alternatively admitted into the cylinder on both sides of the piston. This resulted in a more powerful action, but also in a much more uniform movement of the piston, making the Boulton and Watt double-acting design the state-of-the-art for applications requiring rotary motion. Accordingly, at the end of the eighteenth century, Watt engines probably enjoyed some technical advantage in applications requiring the delivery of a steady rotary motion, such as cotton spinning. From the 1780s, Newcomen engines had also begun to be used to drive textile machinery, but the motion they delivered was rather unsteady (Hills 1970, pp. 141-143). Some ingenious technical solutions that could mitigate this problem were introduced in the early 1790s by Francis Thompson and Bateman and Sherrat for Newcomen engines installed in cotton mills in Lancashire and Nottinghamshire (Hills 1970, pp. 147-148).

Finally, in the second half of the 1790s, Richard Trevithick developed the first high-pressure engine (Watt engines used steam at a little more than atmospheric pressure). This type of engine did not use the separate condenser, but discharged exhaust steam directly into the atmosphere. For this reason, they were called "puffers". The main advantage of this type of engines was their compactness and their cheaper cost of installation due to elimination of the condenser, the air pump and the beam (von Tunzelmann 1978, p. 23). The nineteenth-century development of steam power technology was to be increasingly characterized by the use of higher and higher steam pressures, though usually in combination with condensing.

\section{Spatial diffusion patterns in early steam power technology}

Kanefsky and Robey (1980) have compiled a survey of all the steam engines erected in Great Britain in the course of the eighteenth century. ${ }^{5}$ For each (known) steam engine erected during the period 1700-1800, Kanefsky and Robey recorded the year of construction, the type or design of the engine (i.e. Newcomen, Watt, Hornblower, etc.), the county, and the sector of application. ${ }^{6}$ It is worth remarking that this dataset intends to cover engine construction and not engine utilization. This means that besides the year of erection there is no other information on the time period over which the engine was actually used, and there is no information on the date at which the engine was scrapped or replaced.

As the authors would admit, the data collected by Kanefsky and Robey are probably affected by some biases in both upward and downward directions. The principal source of overestimation is the double counting of engines that were moved from one place to another, whereas underestimation is mainly due to small engines that have left no trace in the records. Notwithstanding these problems (which might result in some revisions in the future), the survey constitutes the most

\footnotetext{
5 See Kanefsky (1979) for a detailed account of the construction of the database.

${ }^{6}$ Other information available for some of the engines is the maker, the cylinder size and the horsepower.
} 
accurate attempt to trace the growth of steam power in Britain over the eighteenth century. In this work, we employ an up-to-date version of this dataset compiled by Kanefsky. ${ }^{7}$

On the basis of the historical outline presented in the previous chapter, the development of steam power technology in the eighteenth century can be divided rather naturally into three distinct "epochs". The first epoch (1700-1733) goes from the invention of the Savery engine to the expiration of the Savery-Newcomen patent. This phase represents the early introduction of the new technology. The second epoch covers the period 1734-1774. The final phase goes from 1775 (the year of the first successful erection of a Watt engine) to 1800 (the year in which Watt's patent for the separate condenser expired).

For analysing the geographical patterns of steam usage in the eighteenth century, the county seems indeed the appropriate unit of analysis. Historians advocating the adoption of a regional perspective have actually used counties to identify the regional economic systems (Pollard 1981; Hudson 1989). Further, Langton has actually argued that the origins of economic regionalism in England are actually based on the growing autonomy of a "county society" during the seventeenth century, so that by the eighteenth century counties represented relatively coherent geographical units characterized by well defined and specific economic concerns and also cemented by well defined common social identities and cultures (Langton 1984). Other studies focussed on specific regional dimensions of the industrialization process such as the dynamics of wages (Hunt 1986) have used county level data.

The maps presented in Fig. 1 provide a preliminary "impressionistic" view of the geographical (county) distribution of the engines erected in these three periods. Darker (lighter) areas indicate a higher (lower) number of engines. White areas indicate that no engines were erected in that particular county. In addition, map 5 represents the geographical distribution of water-wheels (the "predominant" power technology of the period) and map 6 illustrates the prevailing level of coal prices in the various counties in (circa) 1800 (again, darker areas indicate higher prices, lighter areas represent lower prices and in this case white areas correspond to missing values). ${ }^{8}$

Looking at the maps, the spread of steam power technology appears to have been, from the very outset, remarkably wide. ${ }^{9}$ There is some evidence that indicates that is

\footnotetext{
7 The results of a preliminary analysis of diffusion trends in the updated version of Kanefsky data-set have been reported in Nuvolari et al. (2006). The list originally compiled by Kanefsky and Robey contained a total of 2,191 steam engines, the new updated dataset contains 2,279 engines. The updated version of the list has been kindly provided to us by John Kanefsky. Concerning Watt engines, the updated list by Kanefsky contains 479 engines. Tann (1988) on the basis of a careful examination of the Boulton and Watt papers considers this total too high. Her estimation of the engines constructed by Boulton and Watt by 1800 is 449. In this work, mainly for sake of convenience, we have utilised Kanefsky's list without attempting corrections.

${ }^{8}$ The source for the number of water wheels is Kanefsky (1979, pp. 215-216) and for coal prices von Tunzelmann (1978, p. 148).

9 Note that maps 1, 2 and 3 show the distribution of Newcomen and Savery engines considered together. As a consequence, a more precise definition would be "atmospheric engines". Given the relatively small number of Savery engines installed, we have decided to ignore the distinction and maintain the most common usage of Newcomen engines.
} 


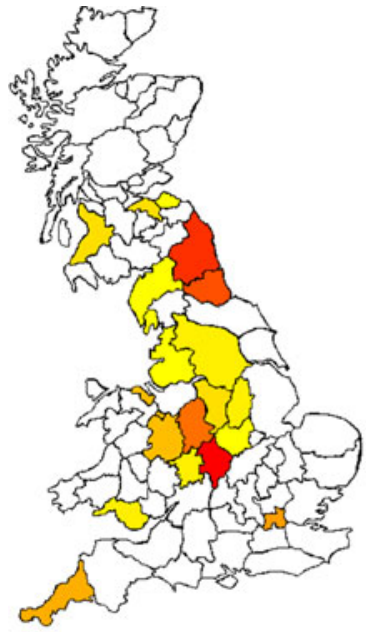

1: Newcomen

Engines, 1700-1733

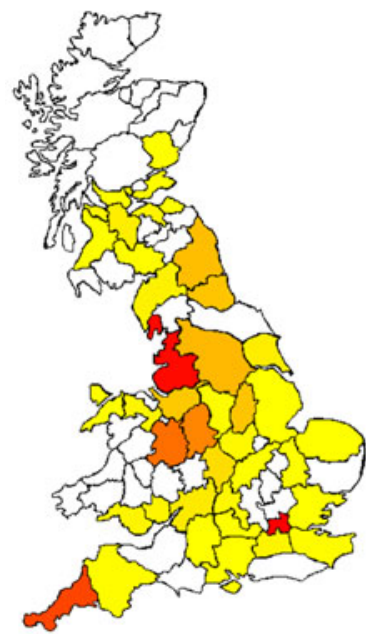

4: Boulton \& Watt Engines, $1775-1800$

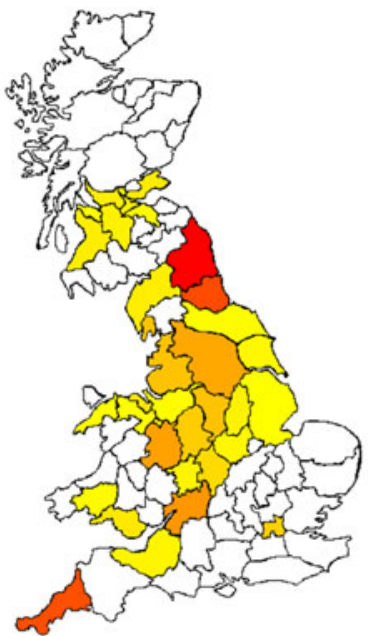

2: Newcomen

Engines, 1734-1774

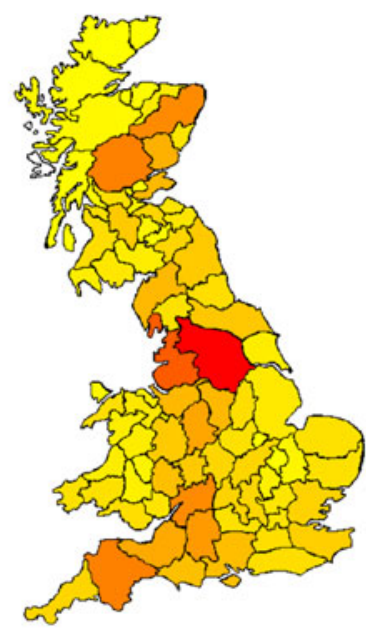

5: Water-wheels, c. 1800

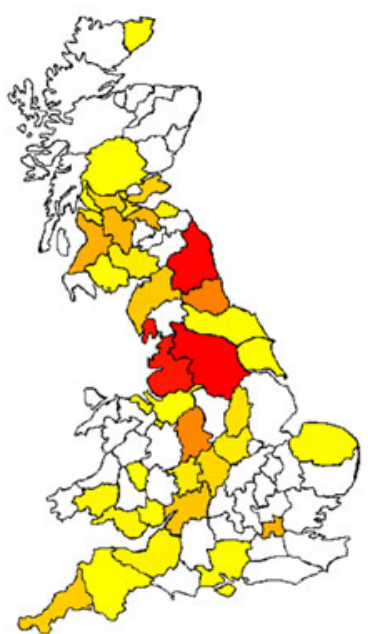

3: Newcomen

Engines, $1775-1800$

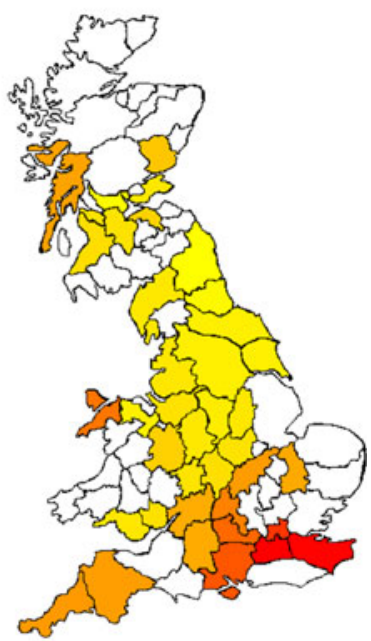

6: Coal prices, c. 1800

Fig. 1 Geographical diffusion of steam technology, 1700-1800

highly likely that the first Newcomen engine was erected in Cornwall at the Wheal Vor tin mine in 1710. However, because of the high price of coal, Cornwall did not represent the most fertile soil for the diffusion of the new technology. The erection of the Wheal Vor engine remained a sporadic event and the introduction of Newcomen engines in Cornish mines actually took place only from the 1720s (Rolt and Allen 1997, p. 45).

Coal mining areas represented of course a much more receptive environment for the new technology, since there coal would be relatively cheap. The Midlands 
coalfields (Stafford and Warwickshire) were the first location where Newcomen engines could take firm root. The commercialisation of the engine was at first controlled by the Newcomen-Savery partnership. As mentioned in the previous chapter, after Savery's death in 1715, a syndicate for the exploitation of the patent rights, the "Committee of Proprietors of the Invention for Raising Water by Fire" was constituted. The Committee, under the direction of its secretary John Meres, promoted rather successfully the use of the engines for drainage in various mining areas by means of a network of agents and licensees. ${ }^{10}$ Apart from the Midlands, as the map of Fig. 1 indicates, by 1733, Newcomen engines, had been adopted in some numbers in Cornwall and in the coalfields in the North East (Northumberland and Durham).

Overall, during the monopoly of the "Proprietors" about one hundred Newcomen engines were constructed. As Smith (1978, p. 12) has aptly remarked, for the time, this must be considered "by any standards a colossal business achievement". On the other hand, it should also be noted that historians (see for example, Flinn 1984, p.117) have generally contended that the high level of royalties claimed by the "Proprietors" (up to $£ 350$ a year) hampered the diffusion process in this initial phase. ${ }^{11}$ Be this as it may, one has to acknowledge that, under the "Proprietors", a group of skilled engine-builders emerged. As we have mentioned in the previous chapter, one of the main merits of Newcomen's invention was its relative easiness of construction and maintenance. Nonetheless, in this initial phase, the engine still represented a rather sophisticated piece of equipment and its erection probably called for more than ordinary engineering skills. Thus, the formation and consolidation of this base of engine-building skills presumably represented a critical factor for the successful introduction of steam power in various locations. Among these engineers we may mention Henry Beighton, who worked for the Parrot-Sparrow partnership and compiled a table containing some rules of thumb for the proportions of the various components of the engine; Joseph Hornblower, who supervised the erection of various engines first in the Midlands and then in Cornwall $^{12}$; Samuel Calley, the son of John Calley (the partner of Thomas Newcomen in the invention of the engine); and Marten Triewald, a Swedish engineer who installed various Newcomen engines in the North East and who would erect a (not very successful) Newcomen engine in Sweden at the Dannemora mine.

In the period 1734-1774 Newcomen engines continued to be built in mining areas. However, as we can we see from map 2, in this phase, steam power also penetrated new locations. This wider spread of the engine was mainly due to its

\footnotetext{
${ }^{10}$ The most active licensee of the "Proprietors" was the partnership formed by Stonier Parrot and George Sparrow who were engaged in the erection of more than fifteen Newcomen engines. According to Flinn (1984, p. 120), the high number of engines erected in Warwick and Stafford (far in excess of the two counties' share in British coal production) is to be accounted for by the fact this was the "home stronghold" of the Parrot-Sparrow partnership. For an account of the activities of Stonier Parrot, see Rowlands (1969).

${ }^{11}$ Kanefsky's data provide some quantitative support for this view. From 1710 to 1733 , 95 SaveryNewcomen engines were constructed. This is approximately equal to 4 engines erected per year. In the period 1734-1774, instead, 442 engines were built, corresponding to 11 engines per year.

12 Joseph Hornblower would decide to settle definitely in Cornwall. He was the grandfather of Jonathan, the inventor of the compound engine.
} 
Table 1 Spatial autocorrelation between engines

\begin{tabular}{llllcc}
\hline $\begin{array}{l}\text { Type of } \\
\text { engine }\end{array}$ & Period & $\begin{array}{l}\text { Number of } \\
\text { engines }\end{array}$ & $\begin{array}{l}\text { Moran I } \\
\text { statistic }\end{array}$ & $\begin{array}{l}\text { Significance } \\
\text { (normal) }\end{array}$ & $\begin{array}{l}\text { Significance } \\
\text { (randomized) }\end{array}$ \\
\hline Newcomen & $1700-1733$ & 97 & 0.167 & $* *$ & $* * *$ \\
Newcomen & $1734-1774$ & 442 & 0.124 & $*$ & $* *$ \\
Newcomen & $1775-1800$ & 616 & 0.192 & $* * *$ & $* * *$ \\
Boulton \& Watt & $1775-1800$ & 479 & 0.074 & & \\
\hline
\end{tabular}

$*, * *, * * *$ indicate significance levels of 10,5 and $1 \%$ respectively

adoption by the iron sector (Shropshire) where it was used to assist water wheels in blowing coke blast furnaces during drought periods (Hyde 1977, pp. 69-75). Newcomen engines also began to be constructed in some numbers in Scotland in the counties of the Clyde Valley. ${ }^{13}$

In this second phase, the "Proprietors" had completely ceased to control the market and Newcomen engines were typically erected by local craftsmen, leaving the cylinder, the cylinder bottom and a small number of other critical components to be manufactured by "specialist" firms and then shipped to the location of the engine. In this respect, it is worth noting that, up to the early 1780s, in Britain there existed only four ironworks that could supply cast iron cylinders for steam engines namely Coalbrookdale and New Willey (in Shropshire), Bersham (in Denbigh) and Carron (Stirling).

The period 1775-1800 is characterized by the competition between Watt and Newcomen engines. In this phase, typically textile counties such as Lancashire and Renfrew (cotton) and West Riding (wool) began to resort to some use of steam to power machinery. The main difference in the spread of the two types of engines is that Watt engines appeared capable of achieving some penetration (although in low numbers) in the counties of the South East, an area which appears, by and large, to exclude Newcomen engines.

Table 1 reports Moran I statistics for the three periods we are considering. Moran I statistic measures whether a variable displays a tendency to be systematically clustered in space, or, on the contrary, it is randomly spread. Higher values of Moran I statistic indicate a stronger degree of spatial autocorrelation. In other words, higher values of the statistic mean that counties with relatively high number of engines tend to be neighbouring (see "Appendix 1", for more details on the calculation of Moran I statistic).

Table 1 shows that Moran I statistic is higher for Newcomen engines than for Watt engines. Notably, in the case of Newcomen engines the coefficient appears to be significantly different from zero both when the original variable is assumed to be characterized by a normal distribution and when it is supposed to be generated by an unspecified one (randomized).

\footnotetext{
${ }^{13}$ For an account of these cases of early installation of Newcomen engines in Scotland, see Hills (2002, p. 297).
} 
On the contrary, the Moran I statistic for Boulton and Watt engines does not turn out to be significant. This seems to indicate that the adoption of Boulton and Watt engines was less susceptible of being conditioned by specific local conditions. This finding may be accounted for by two possible sets of factors acting respectively on the demand and the supply side. On the demand side, given its superior fuel efficiency, it is likely that the adoption of Watt engines was less conditioned by the proximity to cheap coal (this is indeed consistent with the penetration of the Watt engine in the South East of England).

Concerning the possible existence of spatial constraints from the supply side, it is worth noting that apart, from the early period of the "Proprietors", the installation of Newcomen engines was typically in the hands of local millwrights and for this reason, the geographical adoption of the engine could have been limited to areas endowed with the necessary amount of engineering skills. On the contrary, as we shall see, Boulton and Watt instead adopted immediately a much wider horizon in their marketing of steam engines, aiming to serve the entire national market for power.

\section{The diffusion paths at the county level}

The literature on the diffusion of innovations has generally found that the diffusion process follows an S-shaped or sigmoid pattern. The diffusion process takes off rather slowly, then, after a while, it accelerates, and finally it slows down until a certain saturation level is reached (for two insightful overviews of the literature on the diffusion of inventions, see Lissoni and Metcalfe (1994) and Stoneman (2002)). Also in our case, the dynamics of the cumulative number of engines installed seems to follow, in most counties, an S-shaped profile. Following the pioneering contribution of Griliches (1957), it has been common to estimate a simple symmetric logistic growth equation such as (1) in order to provide a characterization of the diffusion process ${ }^{14}$ :

$$
N_{t}=\frac{K}{1+\mathrm{e}^{(-a(t-b))}}
$$

In Eq. 1, $t$ represents time (expressed in years), $N_{t}$ is the number of steam engines installed at time $t, K$ is the saturation level (the number of steam engines that will be installed at the end of the diffusion process), $a$ is a parameter which determines the slope of the curve and the can be understood as a measure of the speed of the diffusion process (the higher the value, the faster the diffusion process), the parameter $b$, instead, defines the position of the curve ( $b$ indicates when the curve reaches the value $K / 2$, that is to say the midpoint of the diffusion process). Some more recent contributions have however found that in some circumstances non symmetric specifications such as the Gompertz growth curve provide a better fit. ${ }^{15}$

\footnotetext{
14 The symmetric logistic curve has been employed by Atack et al. (1980) for providing a characterization of the diffusion process of steam power at regional level in the American case.

15 See Dixon (1980) for an application to the case of hybrid corn studied by Griliches and Geroski (2000) for a more general discussion.
} 
In this perspective, the analysis of data on innovation diffusion using a generalized version of the simple logistic growth equation originally suggested by Richards (1959; see also Birch (1999) for a thorough discussion) in the study of growth processes in the field of botany seems particularly promising. The Richards equation is given by:

$$
N_{t}=\frac{K}{\left(1+T \cdot \mathrm{e}^{(-a(t-b))}\right)^{(1 / T)}}
$$

In Eq. 2 the definition of the variables and parameters is the same of Eq. 1. In comparison to Eqs. 1, 2 contains a fourth shape-parameter, T. It can be shown that the Richards equation encompasses the logistic and the Gompertz as special cases: when the parameter $T=1$ we are in the case of the simple logistic equation, when $T \rightarrow 0$ the Richards equation tends towards the Gompertz growth curve. The chief advantage of the Richards equation is clearly that by containing the additional shape-parameter $\mathrm{T}$, it can be used to characterize a wide variety of sigmoid patterns with different positions of the inflection point. In general, if $T<1$ the inflection point of the curve will be located when $N_{t}<K / 2$, instead if $T>1$ the inflection point will be situated in correspondence of a value of $N_{t}>K / 2$.

Using non linear least squares, we have estimated both the simple logistic equation ("symmetric") and the Richards equation ("generalized") for each county and adopted as preferred model the one that provided a better fit of the data (we have done this exercise for counties with at least 10 engines installed in the period 1700-1800). In order to characterize the relative speed of the diffusion process in each county we have calculated the parameter $\Delta t$, which is the number of years needed to grow from the 10 to the $90 \%$ of the estimated saturation level $K$ (Grubler 1990, pp. 14-15). ${ }^{16}$ The results are reported in Table 2. The full estimates are instead reported in Table 5 in "Appendix 2". The estimated diffusion paths for Newcomen and Watt engines are represented in Figs. 2 and 3 together with the cumulative number of engines (represented by the dots).

In the case of Newcomen engines the generalized specification is preferred in 11 counties whereas the standard symmetric logistic in 10 counties. In the case of Watt engines, instead, the generalized specification is preferred in 2 counties whereas the standard symmetric logistic in 9 . Note that in the case of Newcomen engines, for ten counties the estimates of the parameter $\mathrm{T}$ are greater than 1 . This means that the $\mathrm{S}$ curves display an asymmetric growth pattern where the point of inflection is situated to the right of the point $N_{t}=K / 2$. This finding may perhaps be interpreted as an effect of the competition of Watt engines in the last 25 years of our time window causing a progressive slowing down of the rate of growth of Newcomen engines.

Figure 2 and Table 2 reveal some other interesting aspects of the spread of Newcomen engines. There is a group of "pioneer" counties characterized by relatively fast diffusion rates $(\Delta t<40)$. These locations are Cornwall where steam

\footnotetext{
${ }^{16}$ It can be shown that in the case of the logistic $\Delta t=\frac{\ln 81}{b}$ and in the case of the Richards equation $\Delta t=\frac{\ln \left(10^{T}-1\right)-\ln \left((1 / 0.9)^{T}-1\right)}{b}$.
} 


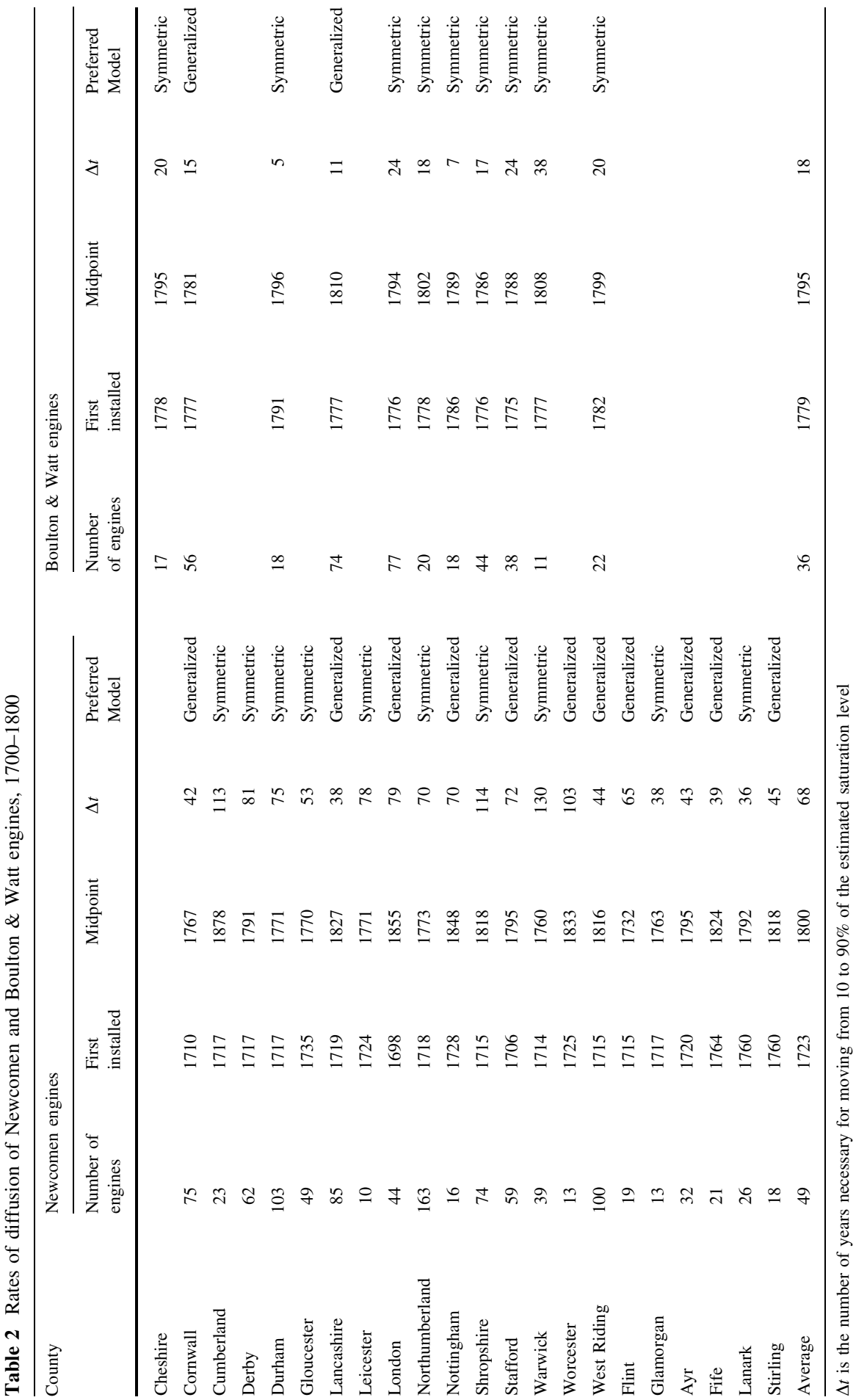



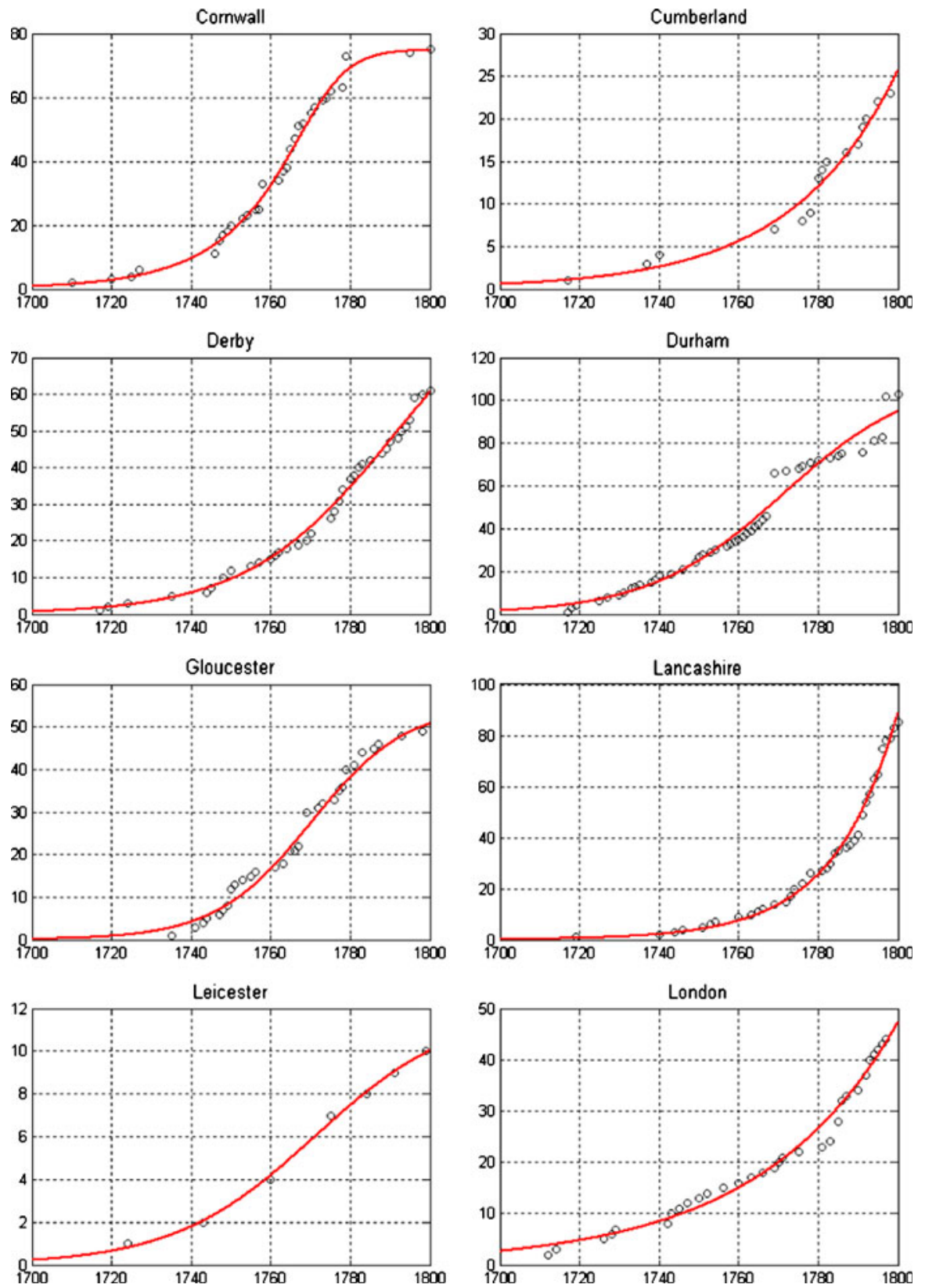

Fig. 2 Estimated diffusion paths for Newcomen engines

engines were employed in copper and tin mines, some typical "textile" counties like Lancashire (cotton) and West Riding and Gloucester (wool) and the Scottish counties (Ayr, Lanark, Fife and Stirling). It is worth noting that in Scotland the 

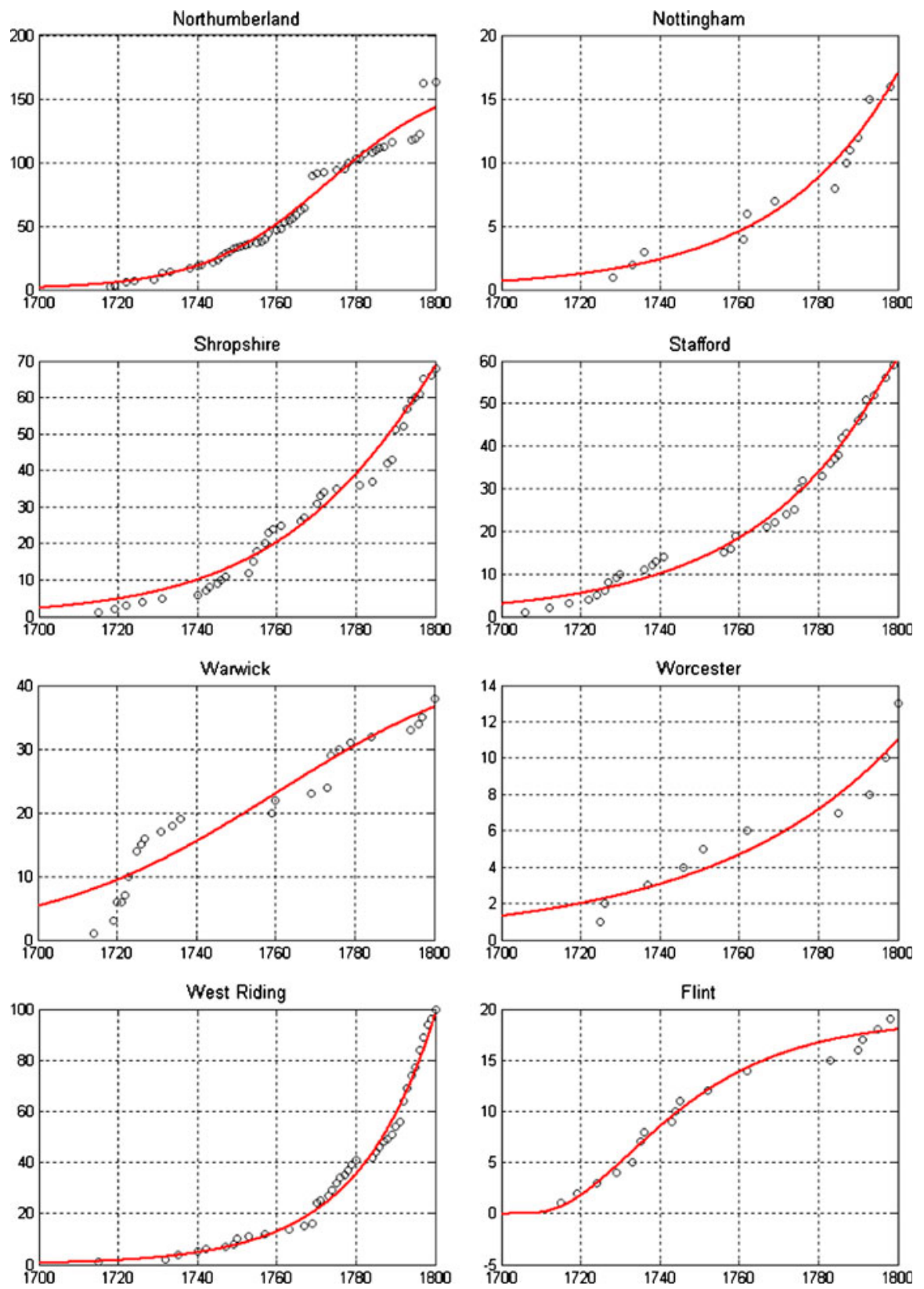

Fig. 2 continued

diffusion begins only in the second half of the eighteenth century (around 1760). Presumably, the establishment of the Carron ironworks (which made use of the cylinder boring machine designed by John Smeaton) in Stirling in 1760 spurred the 

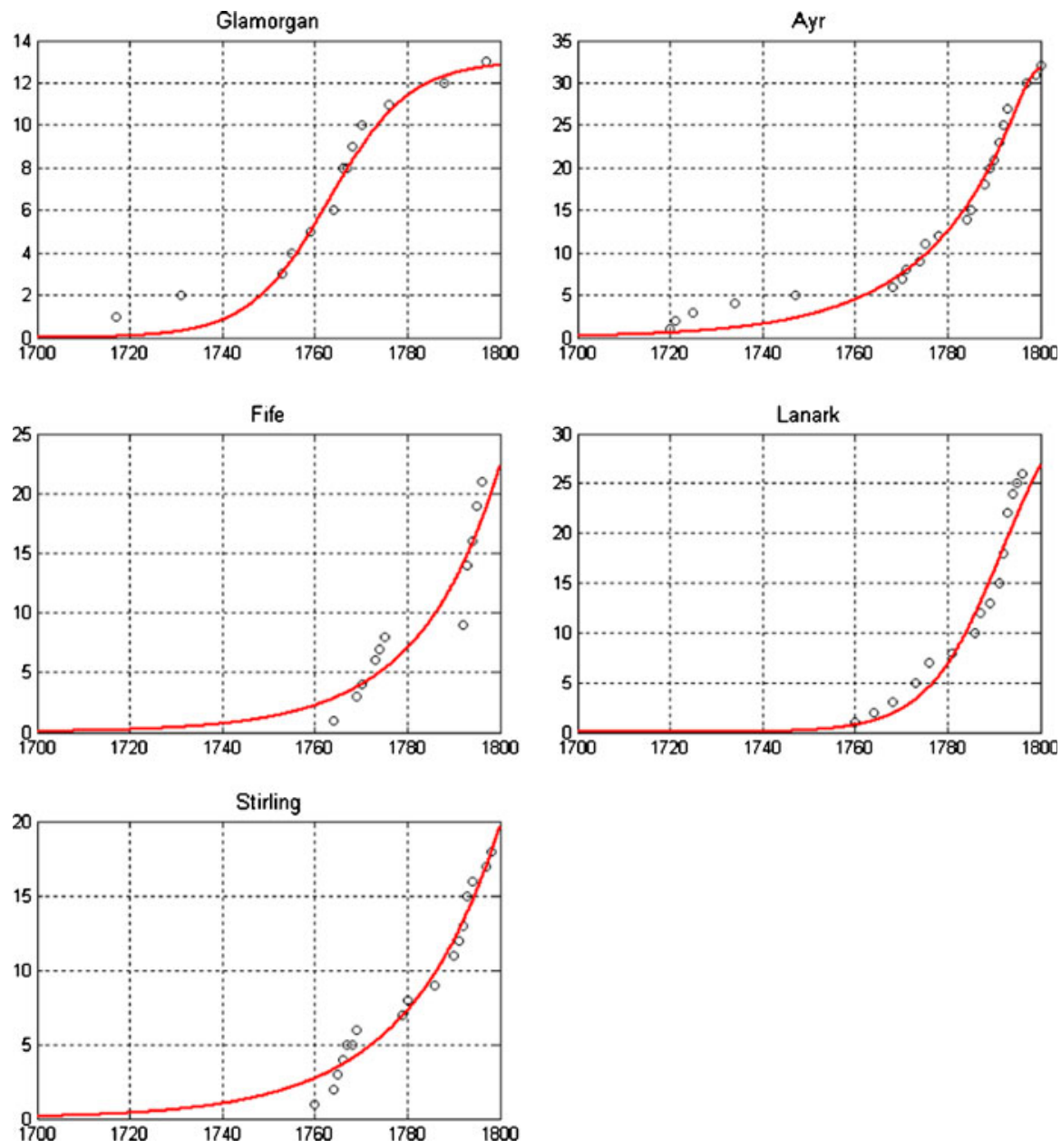

Fig. 2 continued

rapid adoption of steam power in several Scottish counties from the early 1760s. ${ }^{17}$ Coal mining areas of the Midlands (Derby) and of the North East (Northumberland and Durham) together with the London and Nottingham, Stafford and Leicester are characterized by intermediate rates of diffusion $(60<\Delta t<100)$. Finally there is a group of "laggard" counties with relatively slow diffusion rates $(\Delta t>100)$ : Warwick, Shropshire [where from 1743 Newcomen engines where used in ironworks (Trinder 1973)], Cumberland and Worcester.

\footnotetext{
17 In the late $1760 \mathrm{~s}$ and $1770 \mathrm{~s}$, Watt himself was involved in the installation of several Newcomen engines in Scotland. The erection of these engines provided Watt, who was until then acquainted only with experimental models, with a good deal of practical experience with the problems related with the installation and operation of full scale engines (Hills 2002, p. 358).
} 

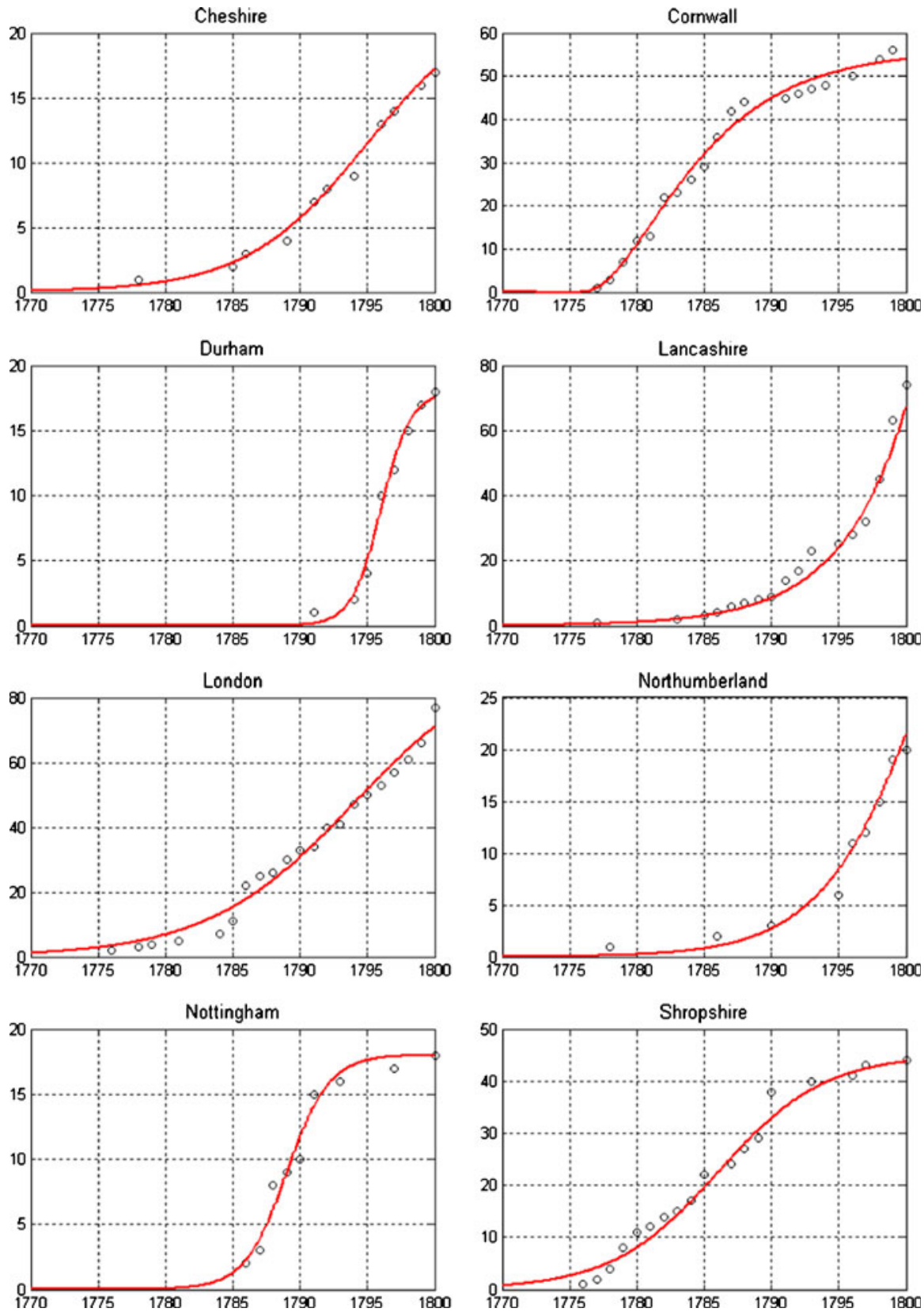

Fig. 3 Estimated diffusion paths for Watt engines

Table 2 also shows that, in general, Boulton and Watt engines were characterized by a faster diffusion rate. The average rate of diffusion $(\Delta t)$ for Newcomen engines is equal to 68 years, whereas for Watt engines it is equal to 18 years. 

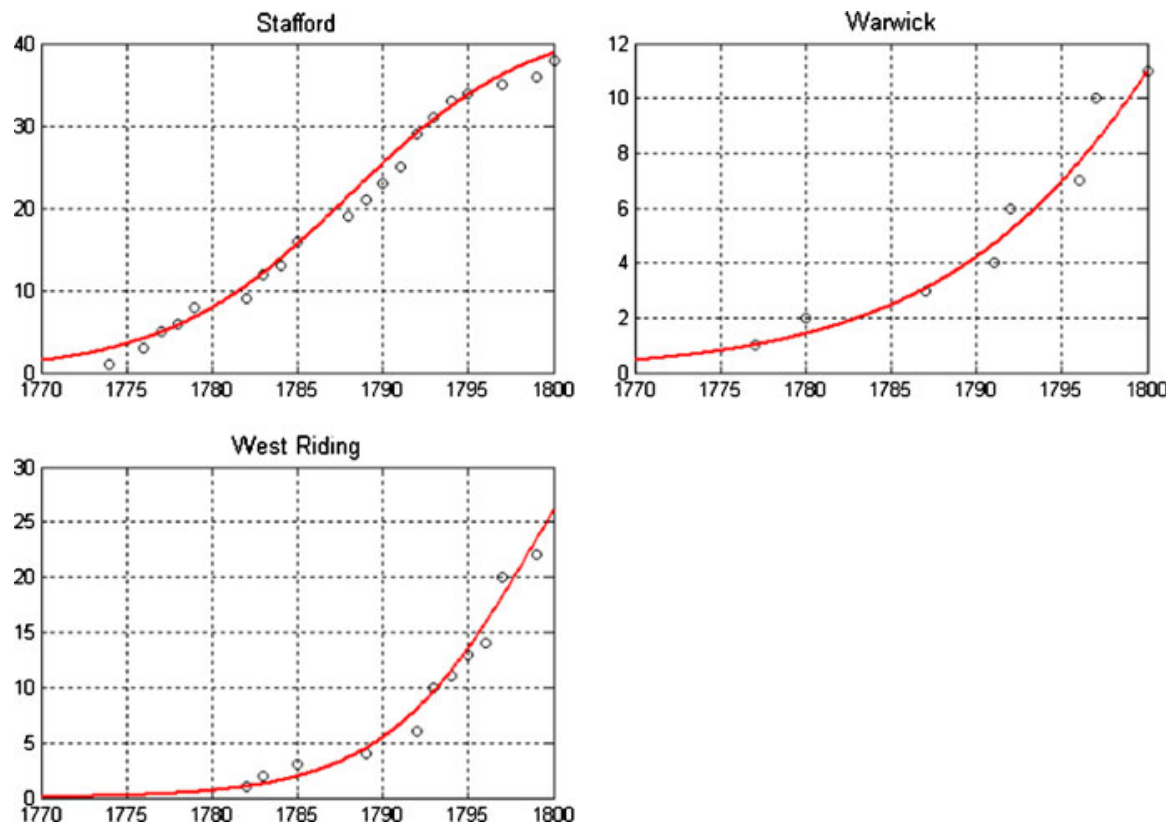

Fig. 3 continued

As in the case of Newcomen engines, the adoption of the Watt engine in various locations also appears to be characterized by a sequential order. Also in the case of Watt engines, we can identify a group of "pioneer" counties such as Cornwall, Shropshire, Northumberland, Durham and Lancashire where the diffusion process is particularly fast $(\Delta t<20)$. We have regions with intermediate rates of diffusion such as Cheshire and West Riding $(\Delta t=20)$. Finally, we have "laggard" counties with relatively slow diffusion rates such as London, Stafford and Warwick $(\Delta t>24)$.

This general exploration of the patterns of diffusion confirms that steam engine technology by the end of the eighteenth century had already become a source of power capable of being used in a wide variety of production processes and in different local contexts. Of course, this exercise is simply meant to provide a broad characterization of the diffusion process in different locations. As noted by Dosi:

...[T]he 'logistic curves' approaches to technological diffusion...show the same descriptive usefulness as well the same limitations of the epidemic curves (or, for that matter, probability models) to which they are formally similar: they show the pattern of diffusion of, say cholera, and they can also relate it to some broad environmental factors, such as the conditions of hygiene of a town, the reproduction time of bacteria, etc. but they cannot explain why some people get it and other do not, which relates to the immunological mechanisms of human bodies, the precise ways bacteria are transmitted, and so on (Dosi 1984, p. 286, italics in the text). 
In other words, our reconstruction of the patterns of diffusion needs to be integrated by further research on the "microbiology" of the diffusion process.

\section{An econometric model of engine adoption for the period 1775-1800}

In order to shed some additional light on the factors driving the spread of steam power technology in this section we estimate "adoption" equations for eighteenth century steam engines using a cross section of counties. We focus on the late eighteenth century (1775-1800) and compare systematically the factors affecting the installation of Newcomen versus Watt engines. Clearly, the aim is to check whether there were noteworthy differences in the factors driving the diffusion process of the two types of engines. Our dependent variable is the number of steam engines (Newcomen or Watt) erected in each county in the period 1775-1800. In both cases, we have a count variable that is skewed, with a non-negligible number of counties having no (i.e., zero) engines. Accordingly, we will make use of negative binomial regressions for estimating the two models (Greene 2000, pp. 880-893; for a thorough treatment of the regression analysis of count data, see also Cameron and Trivedi 1998).

The explanatory variables are:

(i) the price of coal prevailing in the county;

(ii) a dummy indicating the level of coal prices in a dichotomous way (i.e. low/ high, with low being approximately less than $14 \mathrm{~s}$.). This characterization of the price of coal variable permits us to use in the estimation of the regression equation all the counties (84) and not just the 41 for which coal prices are directly available. The dummy variable has been constructed considering the studies of the coal mining industry of Flinn (1984), von Tunzelmann (1986) and Turnbull (1987);

(iii) the number of water-wheels, which can be considered as a proxy for the demand for power (note that in some applications such as ironworks and textiles, steam engines were initially used the operation of water-wheels during drought periods);

(iv) the number of patents in steam technology taken by residents in the county over the period (1698-1801). This variable should capture, admittedly in a rough way, the depth of steam engineering skills existing in the county in question $^{18}$;

(v) the number of blast furnaces in operation existing in the county c. 1800;

(vi) the number of cotton mills existing in the county c. 1800;

(vii) the number of wool mills existing in the county c. 1800;

(viii) for the counties with collieries, the output of coal (in 000s of tons) in 1800;

(ix) a dummy variable indicating the industrial counties: these are the counties identified by Wrigley (2006, p. 19) as those where, in the second half of the eighteenth century, employment in manufacturing was growing fastest.

\footnotetext{
18 In case of patents granted to multiple patentees with residence in different counties, each county was credited with one patent.
} 
By 1831, all these counties had a share of agricultural male employment of less than $20 \%$.

(x) the population of the county in 1801 in (000s).

A complete description of the sources and of the construction of the variables used is given in "Appendix 3". Table 6 in "Appendix 3" reports the descriptive statistics.

Admittedly, our set of explanatory variables is far from covering all the potential factors affecting the diffusion of steam technology in the period in question. Coal prices reflect the cost of a unit of power for the adopter of a steam engine. However the coefficient can also reflect the use of the steam engine in coal mines (as in coal mining areas coal was cheap). We try to control for this latter effect by including in the regression also the coal output mined in counties with collieries. Similarly, the number of water wheels is a proxy for the overall demand of power existing in the county but, at the same time, the variable may also capture some "substitution" or "complementarity" effects between steam and water power. ${ }^{19}$

The sectoral variables (number of blast furnaces, number of cotton mills, number of woollen mills, output of coal), are used as proxies for the size of different branches of economic activities in various counties and control for the different (steam) power requirements of application sectors. They provide a measure of the size of industries (ironworks, textiles and coal mining) that were among the most intensive users of steam power and are included in order to assess the influence of the production structure of the county on the patterns of engine adoption. Note that our coverage of application sectors cannot by any means considered as exhaustive. Lack of suitable data has prevented us from estimating for a sufficient number of counties the size of other sectors which were very intensive users of steam power, such as breweries and waterworks and canals. In order to address this issue, in some specifications we have included the dummy "industry" taken from Wrigley (2006) indicating the counties with the fastest growth in manufacturing employment at the end of the eighteenth century. The variable population is also introduced as an additional control for the different sizes of the counties.

The variable "patents in steam technology" is aimed at capturing the "depth" of steam engineering skills existing in the county in question. Of course this is a very imperfect proxy. As we have already mentioned, the high rates of diffusion for Watt engines estimated in Table 2 were plausibly not only determined by the superior fuel efficiency of the Watt engines, but also by the effectiveness of Boulton and Watt's organisation of steam engine production and marketing techniques. Since the very outset, Boulton and Watt wanted to establish themselves as a leading "national"

\footnotetext{
19 One would expect that abundance of cheap water power in one county had a dilatory effect on steam engine diffusion. However, in many areas steam engines were used in combination of water wheels. In addition, a county characterized by intensive use of water power was likely to be endowed with a strong base of "millwrighting" skills that could have exerted a beneficial effect on the diffusion of steam power technology.
} 
producer of steam engines. ${ }^{20}$ Instead, the construction of Newcomen engines was mainly undertaken by local manufactures with rather narrower and less ambitious business horizons. ${ }^{21}$ In this respect, Roll (1930) and Dickinson (1936) stressed the fundamental role played by Boulton's entrepreneurial and marketing abilities for the success of the partnership. ${ }^{22}$ Boulton's efforts ensured that Watt engines were quickly adopted in a wide range of industrial applications, which before had not made much use of steam power (breweries, textiles, etc.). For example, the erection of the famous Albion Mills in London is frequently pointed out as an example of a successful marketing strategy which succeeded in triggering the interest in steam power of many industrialists (in particular, breweries) in the London area. ${ }^{23}$ Another initiative of Boulton and Watt aimed at broadening the use of steam technology was the publication of small technical booklets (of course only reserved for their customers) providing detailed descriptions of the procedures for erecting and operating their engines. In this way, "distant" customers could hopefully cope with minor technical difficulties without the assistance of Boulton and Watt's men.

Furthermore, Boulton and Watt successfully established standard units of measure for both the fuel efficiency (duty) and the power (horsepower) of steam engines. Note that the establishment of a standardized unit of power was an event

\footnotetext{
${ }^{20}$ In a famous letter to Watt (February 7, 1769), Boulton declining the offer of Watt and Roebuck (the first partner of Watt) of becoming the licensee of the Watt engine in three counties, wrote : “...I was excited by two motives to offer you my assistance which were love for you and love of a money-getting ingenious project. I presumed that your engine would require money, very accurate workmanship and extensive correspondence to make it turn to best advantage and that the best means of keeping up the reputation and doing the invention justice would be to keep the executive part out of the hands of the multitude of empirical engineers, who from ignorance, want of experience and want of necessary convenience would be very liable to produce bad and inaccurate workmanship; all of which would affect the reputation of the invention. To remedy which and produce the most profit, my idea was to settle a manufactory near to my own by the side of our canal where I would erect all the conveniences necessary for the completion of engines and from which manufactory we would serve all the world with engines of all sizes. By these means and your assistance we could engage and instruct some excellent workmen (with more excellent tools that would be worth any man's while to procure for one single engine) could execute the invention 20 per cent cheaper than it would be otherwise executed, and with a great difference of accuracy as there is between the blacksmith and the mathematical instrument maker. It would not be worth my while to make for three counties only, but I find it very well worth to make for all the world" (quoted in Dickinson and Jenkins 1927, pp. 30-31, italics added).

21 For an account of the activities of local producers of atmospheric engines in Lancashire in the second half of the eighteenth century, see Musson and Robinson (1969 pp. 393-426).

22 In his Memoir of Matthew Boulton written in 1809, Watt stressed the role played by Boulton's entrepreneurial abilities (and by his extensive network of acquaintances) for the successful development of the engine partnership: "Boulton...possessed in a high degree the faculty of rendering any new invention of his own or others useful to the publick, by organizing and arranging the processes by which it could be carried on, as well as promoting the sale by his own exertions and by his numerous friends and correspondents" (cited in Dickinson 1936, pp. 195-196).

23 The engines constructed for the Albion Mills were among the first rotary double acting engines constructed by Boulton and Watt. The choice of a plant of the almost unprecedented size of the Albion Mills was meant to attract the maximum of attention towards the new engine. From a strictly economic point of view the undertaking was not successful. However, according to many contemporaries, following the purely "mechanical" success of the mill, double-acting rotary engines were adopted in a variety of industrial mills where direct rotary motion was needed (Westworth 1933). The engine erected at the Albion Mill also convinced some textile manufacturers in the North to install Boulton and Watt engines for powering their mills, see Hills (1970, p. 156).
} 
Table 3 Adoption of Newcomen engines 1775-1800: negative binomial regressions

\begin{tabular}{|c|c|c|c|c|}
\hline & (1) & (2) & (3) & (4) \\
\hline Type & NB 1 & NB 2 & NB 1 & NB 2 \\
\hline Constant & $\begin{array}{l}2.762 * * * \\
(0.464)\end{array}$ & $\begin{array}{l}2.887 * * * \\
(0.530)\end{array}$ & $\begin{array}{l}1.272 * * * \\
(0.258)\end{array}$ & $\begin{array}{l}1.094 * * * \\
(0.339)\end{array}$ \\
\hline Coal price & $\begin{array}{l}-0.119 * * * \\
(0.0372)\end{array}$ & $\begin{array}{l}-0.136 * * * \\
(0.0372)\end{array}$ & & \\
\hline Coal dummy & & & $\begin{array}{l}-1.968^{* * *} \\
(0.376)\end{array}$ & $\begin{array}{l}-2.163^{* * * *} \\
(0.414)\end{array}$ \\
\hline Water-wheels & $\begin{array}{l}0.00193 \\
(0.00177)\end{array}$ & $\begin{array}{l}0.00301 \\
(0.00223)\end{array}$ & $\begin{array}{l}0.00375^{* *} \\
(0.00186)\end{array}$ & $\begin{array}{l}0.00454 * \\
(0.00258)\end{array}$ \\
\hline Blast furnace & $\begin{array}{l}0.0130 \\
(0.0179)\end{array}$ & $\begin{array}{l}0.0103 \\
(0.0284)\end{array}$ & $\begin{array}{l}0.00563 \\
(0.0165)\end{array}$ & $\begin{array}{l}-0.0155 \\
(0.0379)\end{array}$ \\
\hline Cotton mills & $\begin{array}{l}0.000277 \\
(0.00611)\end{array}$ & $\begin{array}{l}0.00224 \\
(0.00923)\end{array}$ & $\begin{array}{l}0.00198 \\
(0.00588)\end{array}$ & $\begin{array}{l}0.0105 \\
(0.0136)\end{array}$ \\
\hline Wool mills & $\begin{array}{l}-0.0160 * \\
(0.00820)\end{array}$ & $\begin{array}{l}-0.0251^{* * *} \\
(0.0102)\end{array}$ & $\begin{array}{l}-0.0156^{*} \\
(0.00849)\end{array}$ & $\begin{array}{l}-0.0121 \\
(0.0121)\end{array}$ \\
\hline Coal output & $\begin{array}{l}0.000636^{* * *} \\
(0.000215)\end{array}$ & $\begin{array}{l}0.000672 * \\
(0.000369)\end{array}$ & $\begin{array}{l}0.000928 * * * \\
(0.000158)\end{array}$ & $\begin{array}{l}0.00104 * * \\
(0.000447)\end{array}$ \\
\hline Steam patents & $\begin{array}{l}0.164 * * \\
(0.0691)\end{array}$ & $\begin{array}{l}0.224 * \\
(0.115)\end{array}$ & $\begin{array}{l}0.183 * * \\
(0.0836)\end{array}$ & $\begin{array}{l}0.293 * * * \\
(0.110)\end{array}$ \\
\hline Population & $\begin{array}{l}0.00160 \\
(0.00259)\end{array}$ & $\begin{array}{l}0.000826 \\
(0.00360)\end{array}$ & $\begin{array}{l}0.000567 \\
(0.00226)\end{array}$ & $\begin{array}{l}0.000210 \\
(0.00280)\end{array}$ \\
\hline Industry dummy & & & $\begin{array}{l}-0.587 \\
(0.410)\end{array}$ & $\begin{array}{l}-0.949 \\
(0.670)\end{array}$ \\
\hline Log-likelihood & -109.9 & -118.0 & -157.1 & -169.2 \\
\hline Pseudo $R^{2}$ & 0.214 & 0.155 & 0.227 & 0.168 \\
\hline Number of counties & 41 & 41 & 84 & 84 \\
\hline
\end{tabular}

Dependent variable is the number of Newcomen engines installed in the period 1775-1800. Standard error in brackets. *,**,*** indicate significance levels of 10,5 , and 1 percent

not only of technical, but especially of economic significance (perhaps one of the main determinants of the successful adoption of the engine in various manufacturing applications). The horsepower unit permitted industrialists to have a rather reliable assessment of their power requirements and it also permitted a rough, but rather effective, cost-benefit analysis of the adoption of various power sources. Rules of thumb soon came into common usage for expressing the power requirements of a number of industrial processes [e.g. in cotton spinning 1 horsepower was typically supposed to drive 100 spindles (Chapman 1971, p. 3)].

From these considerations it is clear that our econometric exercise can hope to provide just a partial appraisal of the determinants of the usage of steam technology in the late eighteenth century. Hence, the results ought to be regarded with care, taking into account not only the possible influence of factors not included in our set 
Table 4 Adoption of Boulton \& Watt engines 1775-1800: negative binomial regressions

\begin{tabular}{|c|c|c|c|c|}
\hline & (1) & (2) & (3) & (4) \\
\hline Type & NB 1 & NB 2 & NB 1 & NB 2 \\
\hline Constant & $\begin{array}{l}1.386^{* * * *} \\
(0.427)\end{array}$ & $\begin{array}{l}1.838 * * * \\
(0.486)\end{array}$ & $\begin{array}{l}0.891 * * * \\
(0.311)\end{array}$ & $\begin{array}{l}0.669 \\
(0.408)\end{array}$ \\
\hline Coal price & $\begin{array}{l}-0.00943 \\
(0.0200)\end{array}$ & $\begin{array}{l}-0.0449 \\
(0.0274)\end{array}$ & & \\
\hline Coal dummy & & & $\begin{array}{l}-1.332 \text { *** } \\
(0.406)\end{array}$ & $\begin{array}{l}-1.943 \text { **** } \\
(0.544)\end{array}$ \\
\hline Water-wheels & $\begin{array}{l}-0.000564 \\
(0.00191)\end{array}$ & $\begin{array}{l}-0.00339 \\
(0.00279)\end{array}$ & $\begin{array}{l}-0.00157 \\
(0.00233)\end{array}$ & $\begin{array}{l}-0.00413 \\
(0.00351)\end{array}$ \\
\hline Blast furnaces & $\begin{array}{l}0.0495 * * * \\
(0.0167)\end{array}$ & $\begin{array}{l}0.0525 * \\
(0.0317)\end{array}$ & $\begin{array}{l}0.0482 * * \\
(0.0198)\end{array}$ & $\begin{array}{l}0.00864 \\
(0.0435)\end{array}$ \\
\hline Cotton mills & $\begin{array}{l}0.00784 \\
(0.00558)\end{array}$ & $\begin{array}{l}0.00277 \\
(0.00857)\end{array}$ & $\begin{array}{l}-0.00417 \\
(0.00536)\end{array}$ & $\begin{array}{l}-0.00871 \\
(0.0102)\end{array}$ \\
\hline Wool mills & $\begin{array}{l}-0.0110 \\
(0.00927)\end{array}$ & $\begin{array}{l}-0.00935 \\
(0.0104)\end{array}$ & $\begin{array}{l}-0.0146 \\
(0.0105)\end{array}$ & $\begin{array}{l}-0.0157 \\
(0.0135)\end{array}$ \\
\hline Coal output & $\begin{array}{l}0.000722^{* * *} \\
(0.000223)\end{array}$ & $\begin{array}{l}0.000372 \\
(0.000342)\end{array}$ & $\begin{array}{l}0.000678^{* * *} * \\
(0.000212)\end{array}$ & $\begin{array}{l}0.000377 \\
(0.000461)\end{array}$ \\
\hline Steam patents & $\begin{array}{l}0.105 \\
(0.0764)\end{array}$ & $\begin{array}{l}0.108 \\
(0.102)\end{array}$ & $\begin{array}{l}-0.0208 \\
(0.0773)\end{array}$ & $\begin{array}{l}0.395^{* *} \\
(0.157)\end{array}$ \\
\hline Population & $\begin{array}{l}0.00148 \\
(0.00231)\end{array}$ & $\begin{array}{l}0.00525 \\
(0.00362)\end{array}$ & $\begin{array}{l}0.00579 * * * \\
(0.00216)\end{array}$ & $\begin{array}{l}0.00988^{* * *} \\
(0.00385)\end{array}$ \\
\hline Industry dummy & & & $\begin{array}{l}0.533 \\
(0.380)\end{array}$ & $\begin{array}{l}0.100 \\
(0.634)\end{array}$ \\
\hline Log-likelihood & -119.8 & -123.4 & -154.5 & -163.4 \\
\hline Pseudo $R^{2}$ & 0.150 & 0.124 & 0.205 & 0.159 \\
\hline Number of counties & 41 & 41 & 84 & 84 \\
\hline
\end{tabular}

Dependent variable is the number of Watt engines installed in the period 1775-1800. Standard error in brackets. $*, * *, * * *$ indicate significance levels of 10,5 , and 1 percent

of explanatory variables, but also that the interpretation of the coefficients of the variables included in the econometric model is by no means straightforward.

Tables 3 and 4 report our estimates for the equations having as dependent variable the number of engines. We have estimated the coefficients considering two different forms of the negative binomial density function. In the first case we have assumed a density function with mean equal to $\mu$ and variance equal to $\mu(1+\delta)$. This case is termed "NB 1" by Cameron and Trivedi (1998, p. 62). In the second case we have assumed that the negative binomial density function has mean equal to $\mu$ and variance equal to $\mu(1+\alpha \mu)$. Cameron and Trivedi (1998, p. 62) refer to this model as "NB 2". It is possible to test for the actual existence of "overdispersion" (i.e., that the variance is larger than the mean) by verifying that $\alpha$ or $\delta$ are different from zero. In our case this was done by means of a likelihood ratio test (Cameron 
and Trivedi 1998, pp. 77-78) that has confirmed the existence of overdispersion supporting our choice of negative binomial estimations.

In this respect, one can note that the existence of overdispersion points to the fact that the data exhibit a higher degree of cross sectional heterogeneity (i.e. clustering in counties with "high" or "low" number of engines), than the case of a spatially homogeneous Poisson process. In other words, the existence of overdispersion reveals a pattern of spatial clustering among counties in terms of their extent of steam usage that goes beyond what can be accounted for by our set of explanatory variables. One could actually suggest that this cross-sectional heterogeneity can be seen as providing an indication of the existence of county-specific absorptive capabilities affecting the spread of steam technology. In general the NB 1 model should probably be the preferred specification in terms of goodness of fit (pseudo $R^{2}$ ), but it is worth noting the coefficients estimated using the NB 1 and NB 2 are consistent with each other.

The price of coal (whose inclusion restricts the sample to 41 counties) is negative and significant in the case of Newcomen engines, where is not significant in case of Watt engines. The marginal effect of the estimated coefficient in the NB 1 specification implies that an increase of the price of coal of 1 shilling would determine a reduction of 0.7 Newcomen engines installed in the county. The coefficient for the coal dummy is negative and significant both for Newcomen and Watt engines. As one could have expected, the negative size of the coefficient for Newcomen engine is larger than the one for Watt engines. In this case, the marginal effects of the estimated coefficients in the NB 1 specification imply that being a high coal price county determines a reduction of 6.2 Newcomen and of 3.6 Watt engines in comparison with a low coal price county with the same characteristics. Our findings, thus, confirm the role of coal prices as the critical variable affecting the choice between Newcomen and Watt engines in our cross-section of counties. Note that the variable coal output has also a positive and significant coefficient of roughly similar size both in Tables 3 and 4.

Curiously enough, in Table 3 the coefficient for number of wool mills variable is significant with a negative sign. This can be accounted for by the peculiarities of the transition to steam power mechanization in the wool textile industry (which was concentrated in Yorkshire (West Riding) and in the West of England). Overall the shift to steam in wool textiles was much slower than in cotton. Furthermore, in this industry, the diffusion of steam technology proceeded at two very different paces in the two areas. In West Riding, atmospheric returning engines were rapidly and rather successfully adopted for power carding and spinning machines (jennies). Table 2 indicates that about Newcomen 100 engines were installed in West Riding by 1800 . Instead in the other wool regions of the West of England (Gloucester, Wiltshire) and of Scotland, steam power technology was introduced very slowly (Jenkins and Ponting 1982, pp. 50-56). The combined effect of these two contrasting patterns of adoption can help explain why the coefficient for wool mills appears significant with a negative sign in some specifications.

In Table 3 the variable "steam patents" has a positive and significant coefficient, showing the positive influence of the level of engineering skills for the adoption of 
engines. ${ }^{24}$ The marginal effect of this coefficient in the NB 1 specification of column 3 implies that having one more patent in steam engineering would determine an increase of 0.4 Newcomen engines installed in the county. There does not seem, instead, to exist a systematic relation between the number of Watt engines and the number of steam patents (the variable is significant only in column 4 of Table 4). This is actually consistent with the fact that Watt engines throughout the eighteenth century (with the exception of "pirate" engines) were installed by only one company owning a proprietary technology.

Finally the coefficient of the variable water-wheels is positive and significant in the models estimated in columns 3 and 4 of Table 3 , whereas the variable is not significant in Table 4 . This result may probably be accounted for by the fact that Newcomen engines delivering rotary motion where often used to pump water for a wheel, whereas Watt engines were more frequently employed providing directly rotary motion (Hills 1989).

In Table 4, the positive and significant coefficient for the variable blast furnaces in the equations for Watt engines is consistent with those historical accounts that have emphasized the rapid adoption of the engine in ironworks type of application (Hyde 1977). The marginal effect of the coefficient estimated using the NB 1 model in column 3 implies that having one more blast furnace would determine an increase of 0.35 Watt engines installed in the county.

\section{Concluding remarks}

In this paper we have provided a reconstruction of the patterns of diffusion and adoption of steam engine technology during the eighteenth century. Furthermore we have also attempted to assess the influence of various explanatory factors on the diffusion process. Our findings indicate that the level of coal prices was indeed one of the major determinants of the distinctive patterns of adoption of Newcomen and Watt engines, giving further support to the previous studies of von Tunzelmann (1978) and Kanefsky (1979). In a broader perspective, this link between coal prices and the intensity of steam power usage is also consistent with Allen (2009) who argues that the successful development of steam power technology in a global perspective can be seen as an outcome of Britain's price structure of relative high wages and cheap coal prices combined with a substantial endowment of engineering skills. Our results, shows that, although this view is broadly accurate, spatial variations in coal prices within Britain are also a part of the story.

However, it is also clear that, together with the level of coal prices, a number of other factors were also at work. In this respect it must be also acknowledged that Newcomen and Watt are rather "broad" categories. The specific design of the engine did not only determine its fuel efficiency, but also the quality of the power delivered (smoothness and regularity of motion, susceptibility to breakages,

\footnotetext{
${ }^{24}$ We have also estimated specifications including as explanatory variable the total number of patents granted over the period 1700-1800 (this may be though to capture a general level of inventive skills, rather than those related with steam engineering), but the variable was not significant.
} 
easiness of maintenance etc.). Not surprisingly, particular engine designs turned out to better suited for specific applications than others (in some cases, despite their level of fuel efficiency). This issue is discussed more in detail in Frenken and Nuvolari (2004).

Our econometric analysis also indicates that, in the course of the eighteenth century, the regional patterns of usage of steam technology displayed considerable spatial diversity, reflecting the direct influence of locational determinants such as the price of coal and the production structure of the various counties, but, possibly, also of more complex and idiosyncratic factors impinging on the capabilities of the individual counties of absorbing the new technology of steam power (as revealed by the existence of "overdispersion" in the negative binomial estimations). In a more general perspective, this finding confirms the need of taking regional differences properly into account when examining the process of technical change during the British industrial revolution (Hudson 1989).

Acknowledgments We would like to thank John W. Kanefsky for providing us with the updated version of his dataset of eighteenth century British steam engines. We are also grateful to Joel Mokyr, Christine MacLeod, Tine Bruland, Jeremy Atack, Onder Nomaler, Roberto Fontana, Liam Brunt and two anonymous referees for helpful comments on previous versions of this paper. The research of Alessandro Nuvolari has been partially funded by Netherlands Organization for Scientific Research (Veni Grant, "Inventive activities, patents and the industrial revolution").

Open Access This article is distributed under the terms of the Creative Commons Attribution Noncommercial License which permits any noncommercial use, distribution, and reproduction in any medium, provided the original author(s) and source are credited.

\section{Appendix 1: The Moran I statistic}

Moran I statistic is essentially a correlation coefficient which assesses the degree of spatial autocorrelation of a spatial variable. Assume that the variable $x$ is defined over a number locations $n$. We can construct a matrix $W$ (spatial contiguity matrix) which indicates whether two counties have borders in common or not. The matrix is symmetric and each element $w_{i j}$ is equal to 1 when the locations $i$ and $j$ a border in common and to 0 otherwise. The elements on the main diagonal of the contiguity matrix are equal to 0 . In this case Moran I statistic is equal to

$$
I=\frac{n \sum_{i=1}^{n} \sum_{j=1}^{n} z_{i} w_{i j} z_{j}}{2 \cdot\left(\sum_{i=1}^{n} \sum_{j=1}^{n} w_{i j}\right) \cdot \sum_{i=1}^{n} z_{i}^{2}}
$$

where is $z_{i}=x_{i}-\bar{x}$ (the deviation of $x_{i}$ from the mean). Higher values of $I$ indicate a stronger degree of (positive) spatial autocorrelation. Cliff and Ord (1981, pp. 42-46) illustrate how to compute significance intervals for Moran's I under two different hypotheses: the first one is that the observations $x$ are normally distributed (normality assumption) whereas the second one (randomised) assumes that the realizations of $x$ were extracted from one of the possible $n$ ! permutations of the $n$ values of the variable $x$ over the $n$ locations. 


\section{Appendix 2: Estimates of diffusion rates}

Table 5 Estimates of diffusion curves

\begin{tabular}{|c|c|c|c|c|c|c|c|c|c|c|}
\hline \multirow[t]{2}{*}{ County } & \multicolumn{5}{|c|}{ Newcomen } & \multicolumn{5}{|c|}{ Boulton \& Watt } \\
\hline & $K$ & $a$ & $b$ & $T$ & $R^{2}$ & $K$ & $a$ & $b$ & $T$ & $R^{2}$ \\
\hline Cheshire & & & & & & $\begin{array}{l}23 \\
(3)\end{array}$ & $\begin{array}{l}0.220 \\
(0.025)\end{array}$ & $\begin{array}{l}1795 \\
(1)\end{array}$ & & 0.99 \\
\hline Cornwall & $\begin{array}{l}75 \\
(4)\end{array}$ & $\begin{array}{l}0.186 \\
(0.101)\end{array}$ & $\begin{array}{l}1767 \\
(1)\end{array}$ & $\begin{array}{l}2.98 \\
(1.83)\end{array}$ & 0.99 & $\begin{array}{l}56 \\
(4)\end{array}$ & $\begin{array}{l}0.173 \\
(0.103)\end{array}$ & $\begin{array}{l}1781 \\
(1)\end{array}$ & $\begin{array}{l}-0.40 \\
(0.64)\end{array}$ & 0.99 \\
\hline Cumberland & $\begin{array}{l}564 \\
(374)\end{array}$ & $\begin{array}{l}0.039 \\
(0.012)\end{array}$ & $\begin{array}{l}1878 \\
(325)\end{array}$ & & 0.97 & & & & & \\
\hline Derby & $\begin{array}{l}98 \\
(9)\end{array}$ & $\begin{array}{l}0.054 \\
(0.003)\end{array}$ & $\begin{array}{l}1791 \\
(3)\end{array}$ & & 0.99 & & & & & \\
\hline Durham & $\begin{array}{l}112 \\
(7)\end{array}$ & $\begin{array}{l}0.059 \\
(0.005)\end{array}$ & $\begin{array}{l}1771 \\
(3)\end{array}$ & & 0.97 & $\begin{array}{l}18 \\
(1)\end{array}$ & $\begin{array}{l}0.910 \\
(0.145)\end{array}$ & $\begin{array}{l}1796 \\
(1)\end{array}$ & & 0.99 \\
\hline Gloucester & $\begin{array}{l}55 \\
(2)\end{array}$ & $\begin{array}{l}0.083 \\
(0.005)\end{array}$ & $\begin{array}{l}1770 \\
(1)\end{array}$ & & 0.99 & & & & & \\
\hline Lancashire & $\begin{array}{l}644 \\
(242)\end{array}$ & $\begin{array}{l}0.347 \\
(0.256)\end{array}$ & $\begin{array}{l}1827 \\
(14)\end{array}$ & $\begin{array}{l}5.60 \\
(3.90)\end{array}$ & 0.90 & $\begin{array}{l}697 \\
(1)\end{array}$ & $\begin{array}{l}1.448 \\
(0.120)\end{array}$ & $\begin{array}{l}1810 \\
(1)\end{array}$ & $\begin{array}{l}7.04 \\
(0.88)\end{array}$ & 0.98 \\
\hline Leicester & $\begin{array}{l}12 \\
(1)\end{array}$ & $\begin{array}{l}0.056 \\
(0.005)\end{array}$ & $\begin{array}{l}1771 \\
(3)\end{array}$ & & 1.00 & & & & & \\
\hline London & $\begin{array}{l}293 \\
(1)\end{array}$ & $\begin{array}{l}0.253 \\
(0.016)\end{array}$ & $\begin{array}{l}1855 \\
(2)\end{array}$ & $\begin{array}{l}8.83 \\
(0.39)\end{array}$ & 0.98 & $\begin{array}{l}95 \\
(12)\end{array}$ & $\begin{array}{l}0.182 \\
(0.022)\end{array}$ & $\begin{array}{l}1794 \\
(2)\end{array}$ & & 0.98 \\
\hline Northumberland & $\begin{array}{l}169 \\
(12)\end{array}$ & $\begin{array}{l}0.063 \\
(0.005)\end{array}$ & $\begin{array}{l}1773 \\
(3)\end{array}$ & & 0.97 & $\begin{array}{l}57 \\
(64)\end{array}$ & $\begin{array}{l}0.249 \\
(0.088)\end{array}$ & $\begin{array}{l}1802 \\
(8)\end{array}$ & & 0.98 \\
\hline Nottingham & $\begin{array}{l}110 \\
(13)\end{array}$ & $\begin{array}{l}0.215 \\
(0.528)\end{array}$ & $\begin{array}{l}1848 \\
(11)\end{array}$ & $\begin{array}{l}6.54 \\
(17.71)\end{array}$ & 0.96 & $\begin{array}{l}18 \\
(1)\end{array}$ & $\begin{array}{l}0.636 \\
(0.108)\end{array}$ & $\begin{array}{l}1789 \\
(1)\end{array}$ & & 0.97 \\
\hline Shropshire & $\begin{array}{l}205 \\
(104)\end{array}$ & $\begin{array}{l}0.038 \\
(0.005)\end{array}$ & $\begin{array}{l}1818 \\
(21)\end{array}$ & & 0.98 & $\begin{array}{l}45 \\
(2)\end{array}$ & $\begin{array}{l}0.253 \\
(0.022)\end{array}$ & $\begin{array}{l}1786 \\
(1)\end{array}$ & & 0.98 \\
\hline Stafford & $\begin{array}{l}61 \\
(9)\end{array}$ & $\begin{array}{l}0.764 \\
(1.288)\end{array}$ & $\begin{array}{l}1795 \\
(5)\end{array}$ & $\begin{array}{l}25.06 \\
(42.03)\end{array}$ & 0.99 & $\begin{array}{l}43 \\
(2)\end{array}$ & $\begin{array}{l}0.186 \\
(0.012)\end{array}$ & $\begin{array}{l}1788 \\
(1)\end{array}$ & & 0.99 \\
\hline Warwick & $\begin{array}{l}46 \\
(9)\end{array}$ & $\begin{array}{l}0.034 \\
(0.008)\end{array}$ & 1760 & & 0.91 & $\begin{array}{l}39 \\
(76)\end{array}$ & $\begin{array}{l}0.117 \\
(0.050)\end{array}$ & $\begin{array}{l}1808 \\
(26)\end{array}$ & & 0.96 \\
\hline Worcester & $\begin{array}{l}26 \\
(4)\end{array}$ & $\begin{array}{l}0.396 \\
(0.064)\end{array}$ & $\begin{array}{l}1833 \\
(2)\end{array}$ & $\begin{array}{l}18.57 \\
(0.40)\end{array}$ & 0.91 & & & & & \\
\hline West riding & $\begin{array}{l}261 \\
(1)\end{array}$ & $\begin{array}{l}0.819 \\
(0.041)\end{array}$ & $\begin{array}{l}1816 \\
(1)\end{array}$ & $\begin{array}{l}16.21 \\
(0.75)\end{array}$ & 0.99 & $\begin{array}{l}47 \\
(25)\end{array}$ & $\begin{array}{l}0.224 \\
(0.053)\end{array}$ & $\begin{array}{l}1799 \\
(4)\end{array}$ & & 0.97 \\
\hline Flint & $\begin{array}{l}19 \\
(2)\end{array}$ & $\begin{array}{l}0.043 \\
(0.224)\end{array}$ & $\begin{array}{l}1732 \\
(12)\end{array}$ & $\begin{array}{l}-0.31 \\
(3.49)\end{array}$ & 0.98 & & & & & \\
\hline Glamorgan & $\begin{array}{l}13 \\
(1)\end{array}$ & $\begin{array}{l}0.116 \\
(0.018)\end{array}$ & $\begin{array}{l}1763 \\
(1)\end{array}$ & & 0.97 & & & & & \\
\hline
\end{tabular}


Table 5 continued

\begin{tabular}{|c|c|c|c|c|c|c|c|c|c|c|}
\hline \multirow[t]{2}{*}{ County } & \multicolumn{5}{|c|}{ Newcomen } & \multicolumn{5}{|c|}{ Boulton \& Watt } \\
\hline & $K$ & $a$ & $b$ & $T$ & $R^{2}$ & $K$ & $a$ & $b$ & $T$ & $R^{2}$ \\
\hline Ayr & $\begin{array}{l}32 \\
(5)\end{array}$ & $\begin{array}{l}0.939 \\
(1.77)\end{array}$ & $\begin{array}{l}1795 \\
(3)\end{array}$ & $\begin{array}{l}18.25 \\
(35.91)\end{array}$ & 0.98 & & & & & \\
\hline Fife & $\begin{array}{l}113 \\
(7)\end{array}$ & $\begin{array}{l}0.507 \\
(0.093)\end{array}$ & $\begin{array}{l}1824 \\
(8)\end{array}$ & $\begin{array}{l}8.85 \\
(1.12)\end{array}$ & 0.87 & & & & & \\
\hline Lanark & $\begin{array}{l}37 \\
(8)\end{array}$ & $\begin{array}{l}0.122 \\
(0.027)\end{array}$ & $\begin{array}{l}1792 \\
(4)\end{array}$ & & 0.95 & & & & & \\
\hline Stirling & $\begin{array}{l}60 \\
(1)\end{array}$ & $\begin{array}{l}0.537 \\
(0.037)\end{array}$ & $\begin{array}{l}1818 \\
(1)\end{array}$ & $\begin{array}{l}10.83 \\
(0.17)\end{array}$ & 0.97 & & & & & \\
\hline
\end{tabular}

Standard errors in brackets. When $T$ is not given, the standard symmetric logistic equation was estimated, otherwise the generalized form (Richards growth equation) was used. The symmetric logistic has analytical standard errors, whereas the generalized form has bootstrapped standard errors

\section{Appendix 3: Sources and construction of the data}

Number of steam engines ("atmospheric" and Boulton \& Watt) installed during the period 1775-1800: Data taken from the updated version of the Kanefsky and Robey (1980) list.

Price of Coal, c. 1800: Data taken from von Tunzelmann (1978, p. 148). The 41 counties for which coal prices were available are:

Cornwall, Devon, Wiltshire, Hampshire, Berkshire, Surrey, Middlesex (London), Kent, Cambridge, Northampton, Oxford, Leicester, Warwick, Worcester, Gloucester, Monmouth, Glamorgan, Shropshire, Stafford, Anglesey, Caernarvon, Denbigh, Cheshire, Derby, Nottingham, Lancashire, East Riding, West Riding, North Riding, Durham, Northumberland, Cumberland, Ayr, Renfrew, Lanark, Stirling, Argyll, Clackmannan, Midlothian, Fife, Angus.

Coal dummy, c. 1800: The variable distinguishes between "cheap" and "dear" coal counties. Counties with coal prices higher than $16 \mathrm{~s}$. per ton are considered as having a "high" price of coal. The counties have been assigned on the basis of the price list in von Tunzelmann (1978, p. 148) and of the maps and discussion of Flinn (1984), von Tunzelmann (1986) and Turnbull (1987).

Low coal price counties: Cheshire, Cumberland, Derby, Durham, Lancashire, Leicester, Monmouth, Northumberland, Nottingham, Shropshire, Stafford, Warwick, Worcester, West Riding, East Riding, Carmarthen, Denbigh, Flint, Glamorgan, Pembroke, Angus, Ayr, Berwick. Clackmannan, Dunbarton, East Lothian, Fife, Kinross, Lanark, Midlothian, Renfrew, Stirling, West Lothian.

High coal price counties: Bedford, Berkshire, Buckingham, Cambridge, Cornwall, Devon, Dorset, Essex, Gloucester, Hampshire, Hereford, Hertford, Huntingdon, Kent, Lincoln, Middlesex (London), Norfolk, Northampton, Oxford, Rutland, Somerset, Suffolk, Surrey, Sussex, Westmorland, Wiltshire, North Riding, 
Anglesey, Brecknock, Caernarvon, Cardigan, Merioneth, Montgomery, Radnor, Aberdeen, Argyll, Banff, Caithness, Dumfries, Inverness, Kincardine, Kircudbright, Moray, Nairn, Peebles, Perth, Ross and Cromarty, Roxburgh, Selkirk, Sutherland, Wigtown.

Steam engineering patents, 1700-1800: Steam patents are taken from Abridgments of Specifications relative to the Steam Engine, London, 1871. In order to retrieve the stated residence of the patentees, these patents have been matched with those contained in B. Woodcroft, Titles of Patents of Invention Chronologically Arranged, London, 1854.

Coal output in 1800: Data (in 000s of tons) are taken from Flinn (1984), pp. 26-27.

Population in 1801: Data for English counties are taken from Wrigley (2006). Welsh and Scottish counties are taken from Comparative Statement of the Population of the Several Counties of Great Britain in the years 1801 and 1811 (London, House of Commons, 1812).

Water-wheels, c.1800: Data taken from Kanefsky (1979), pp. 215-216. The data have been constructed on the basis of contemporary maps (i.e. they are presumably likely to underestimate the actual figures). For more details, see Kanefsky (1979).

Blast furnaces, c. 1800: Data taken from Scrivenor (1854). The original source is a government survey after the proposal of a tax on coal. The data refer to the year 1796. For a discussion of this source, see Evans (1993).

Cotton Mills, c. 1800: Data taken from Chapman (1970, pp. 257-266). Chapman's figures are based on insurance records and they mostly refer to the year 1795. For Lancashire we have estimated a figure of 204 mills, which is based on the assumption that the county had $50 \%$ of large mills (types B and C) and $50 \%$ of type A (i.e., small) mills. This is in line with the considerations contained in Chapman's paper.

Wool Mills, c. 1800: Data taken from Chapman (1970, pp. 257-266). Chapman's figures are based on insurance records and they mostly refer to the year 1795. For Lancashire we have estimated a figure of 204 mills, which is based on the assumption that the county had $50 \%$ of large mills (types B and C) and $50 \%$ of type A (i.e., small) mills. This is in line with the considerations contained in Chapman's paper.

Industry dummy, c. 1800: This dummy variable indicates the counties where in the second half of the eighteenth century manufacturing employment was growing fastest (Wrigley 2006, p. 19). We have considered also the "London group" (London \& Middlesex, Surrey and Kent) discussed by Wrigley as a separate group as belonging to this industrial group (Table 6). 
Table 6 Descriptive statistics

\begin{tabular}{lcllc}
\hline Variable & Mean & Min & Max & SD \\
\hline Newcomen engines, 1775-1800 & 7.297619 & 0 & 72 & 15.22109 \\
Boulton \& Watt engines, 1775-1800 & 6.392857 & 0 & 90 & 16.42142 \\
Price of coal in s., c. 1800 & 16.71341 & 6.333333 & 46.66667 & 10.43959 \\
Coal dummy & 0.607143 & 0 & 1 & 0.491319 \\
Water mills, c. 1800 & 118.631 & 10 & 700 & 108.2037 \\
Blast furnaces, c. 1800 & 1.380952 & 0 & 23 & 4.315578 \\
Cotton mills, c. 1800 & 5.214286 & 0 & 204 & 23.97492 \\
Wool mills, c. 1800 & 5.380952 & 0 & 102 & 15.81817 \\
Steam patents, 1700-1800 & 0.869048 & 0 & 21 & 2.687677 \\
Coal output (in 000 of tons), c. 1800 & 179.1071 & 0 & 2,225 & 439.018 \\
Industry dummy & 0.119048 & 0 & 1 & 0.32579 \\
Population in 1801 (in 000s) & 128.5435 & 5.07 & 855.615 & 142.9887 \\
\hline
\end{tabular}

\section{References}

Allen RC (2009) The British industrial revolution in global perspective. Cambridge University Press, Cambridge

Atack J, Bateman F, Weiss T (1980) The regional diffusion and adoption of the steam engine in American manufacturing. J Econ Hist 40:281-308

Berg M, Hudson P (1992) Rehabilitating the industrial revolution. Econ Hist Rev 45:24-50

Birch CPD (1999) A new generalized logistic sigmoid growth equation compared with the Richards growth equation. Ann Bot 83:713-723

Bresnahan T (2010) General purpose technologies. In: Hall BH, Rosenberg N (eds) Handbook of the economics of innovation. Elsevier, Amsterdam, pp 761-791

Cameron AC, Trivedi PK (1998) Regression analysis of count data. Cambridge University Press, Cambridge

Chapman SD (1970) Fixed capital formation in the British cotton industry, 1770-1815. Econ Hist Rev 23:235-266

Chapman SD (1971) The cost of power in the industrial revolution in Britain. The case of the textile industry. Midl Hist 1:1-23

Cipolla CM (1962) The economic history of the world population. Harmondsworth, Penguin

Cliff AD, Ord JK (1981) Spatial processes: models and applications. Pion, London

Crafts N (2004a) Steam as a general purpose technology. A growth accounting perspective. Econ J 114:338-351

Crafts N (2004b) Productivity Growth In The Industrial Revolution. A new growth accounting perspective. J Econ Hist 64:521-535

Crafts N, Harley K (1992) Output growth and the British industrial revolution: a restatement of the Crafts-Harley view. Econ Hist Rev 45:703-730

Dickinson HW (1936) Matthew Boulton. Cambridge University Press, Cambridge

Dickinson HW, Jenkins R (1927) James Watt and the steam engine. Clarendon, Oxford

Dixon R (1980) Hybrid corn revisited. Econometrica 48:1451-1461

Dosi G (1984) Technical change and industrial transformation. The theory and an application to the semiconductor industry. MacMillan, London

Evans C (1993) The statistical surveys of the British Iron industry in 1797-98 and in 1806. J Hist Metall Soc 27:84-101

Flinn MW (1984) The history of the British coal industry, 1700-1830, vol II. Clarendon Press, Oxford

Frenken K, Nuvolari A (2004) The early development of the steam engine: an evolutionary interpretation using complexity theory. Ind Corp Change 13:419-450

Geroski PA (2000) Models of technology diffusion. Res Policy 29:603-625 
Greene WH (2000) Econometric analysis, 4th edn. Prentice-Hall, Upper Saddle River

Griliches Z (1957) Hybrid corn: an exploration in the economics of technological change. Econometrica 25:501-522

Grubler A (1990) The rise and fall of infrastructures. Dynamics of evolution and technical change in transport. Physica-Verlag, Heidelberg

Hills RL (1970) Power in the industrial revolution. Manchester University Press, Manchester

Hills RL (1989) Power from steam. A history of the stationary steam engine. Cambridge University Press, Cambridge

Hills RL (2002) James Watt: his time in Scotland, 1736-1774. Landmark, Ashbourne

Hudson P (1989) The regional perspective. In: Hudson P (ed) Regions and industries: a perspective on the industrial revolution in Britain. Cambridge University Press, Cambridge

Hunt EH (1986) Industrialization and regional inequality: wages in Britain, 1760-1913. J Econ Hist 46:935-966

Hyde CK (1977) Technological Change and the British Iron Industry, 1700-1870. Princeton University Press, Princeton

Jenkins DT, Ponting KG (1982) The British wool textile industry, 1770-1850. Heinemann, London

Kanefsky JW (1979) The diffusion of power technology in British industry, 1760-1870. PhD Thesis, University of Exeter

Kanefsky JW, Robey J (1980) Steam engines in 18th century Britain: a quantitative assessment. Technol Cult 21:161-186

Landes DS (1969) The unbound prometheus. Technological change and industrial development in Western Europe from 1750 to the present. Cambridge University Press, Cambridge

Langton J (1984) The industrial revolution and the regional geography of England. Trans Inst Brit Geogr 9:145-167

Lipsey R, Carlaw K, Bekar C (2005) Economic transformations. General purpose technologies and long term economic growth. Oxford University Press, Oxford

Lissoni F, Metcalfe JS (1994) Diffusion of innovation ancient and modern: a review of the main themes. In: Rothwell R, Dogdson M (eds) Handbook of industrial innovation, Edward Elagar, Aldershot

Musson AE, Robinson EH (1969) Science and technology in the industrial revolution. Manchester University Press, Manchester

Nuvolari A, Verspagen B (2009) Technical choice, innovation and British steam engineering, 1800-1850. Econ Hist Rev 62:685-710

Nuvolari A, Verspagen B, von Tunzelmann GN (2006) The diffusion of the steam engine in eighteenth century Britain. In: Pyka A, Hanusch H (eds) Applied evolutionary economics and the knowledge based economy. Edward Elgar, Aldershot

Pollard S (1981) Peaceful conquest. The industrialization of Europe 1760-1970. Oxford University Press, Oxford

Richards FJ (1959) A flexible growth function for empirical use. J Exp Bot 10:290-300

Roll E (1930) An early experiment in industrial organisation. Being a history of the firm of Boulton \& Watt, 1775-1805. Longman, London

Rolt LTC, Allen JS (1997) The steam engine of Thomas Newcomen, 1st edn. Landmark, Ashbourne

Rostow WW (1960) The stages of economic growth. A non-communist manifesto. Cambridge University Press, Cambridge

Rowlands MB (1969) Stonier Parrot and the Newcomen Engine. Trans Newcomen Soc 41:49-67

Scrivenor H (1854) History of the iron trade. Longmans, London

Smith A (1978) Steam and the city: the Committee of Proprietors of the Invention for Raising Water by Fire, 1715-1735. Trans Newcomen Soc 49:5-20

Stoneman P (2002) The economics of technological diffusion. Blackwell, Oxford

Tann J (1988) Fixed capital formation in steam power, 1775-1825. A case study of the Boulton and Watt engine. In: Feinstein $\mathrm{CH}$, Pollard $\mathrm{S}$ (eds) Studies in capital formation in the United Kingdom, 1750-1920. Clarendon Press, Oxford

Trinder B (1973) The industrial revolution in Shropshire, Phillipmore, Chichister

Turnbull G (1987) Canals, coal and regional growth during the industrial revolution. Econ Hist Rev 40:537-560

von Tunzelmann GN (1978) Steam power and British industrialization to 1860. Clarendon, Oxford

von Tunzelmann GN (1986) Coal and steam power. In: Langton J, Morris RJ (eds) Atlas of industrializing Britain. Methuen, London

Westworth OE (1933) The Albion Steam Flour Mill. Econ Hist 2:380-395 
Wrigley EA (1988) Continuity, chance and change. The character of the industrial revolution in England. Cambridge University Press, Cambridge

Wrigley EA (2004) Poverty, progress and population. Cambridge University Press, Cambridge

Wrigley EA (2006) English county populations in the later eighteenth century. Econ Hist Rev 65:1-41 